\title{
POLITYKA PIĄTEJ I SZÓSTEJ GENERACJ I PRZYWÓDCÓW CHIŃSKICH. KONTYNUACJA CZY ZMIANY SYSTEMOWE?
}

\section{Wprowadzenie}

W systemach niedemokratycznych o autorytarnej charakterystyce sprawująca rządy elita sama określa normy i zasady sukcesji władzy tak, aby nastąpiło jej bezpieczne przekazanie oczekiwanym następcom. W monarchiach mechanizmy transferu opierają się zazwyczaj na założeniu utrzymania władzy przez dynastię. W systemach jednopartyjnych (lub z kierowniczą rolą jednej partii w państwie) nadrzędnym celem zmian personalnych w najwyższych organach władzy jest zapewnienie przez partię jej ciągłości, utrzymanie kontroli nad całokształtem funkcjonowania państwa i zdolności do rządzenia oraz uzyskanie tego społecznej legitymizacji poprzez narzucony system porządku prawnego. Następuje to wskutek zachowania instytucji i procedur umożliwiających sukcesję władzy zgodnie z preferencjami rządzących ${ }^{1}$.

W 2012 roku rozpoczyna się w Chinach proces przejmowania władzy przez młodsze pokolenie polityków, które poprowadzi państwo przez kolejną dekadę, oraz wyznaczenia liderów następnej, szóstej generacji władz. Podczas zaplanowanego na listopad tego roku XVIII Zjazdu Komunistycznej Partii Chin (KPCh) rządząca czwarta generacja chińskich przywódców ustąpi miejsca piątej od czasu proklamowania 1 października 1949 roku Chińskiej Republiki Ludowej ekipie chińskich liderów, a Hu Jintao ostatecznie przekaże władzę nowemu Przewodniczącemu ChRL w 2013 roku w trakcie posiedzenia Ogólnochińskiego Zgromadzenia Przedstawicieli Ludowych (OZPL). Wydarzenie to będzie miało istotne znaczenie dla Chin, sytuacji międzynarodowej i światowej gospodarki. Mimo że zgodnie z chińską tradycją przejmowanie władzy jest dość transparentne w wyznaczeniu głowy państwa i szefa rządu, pozostawia ono wiele niewiadomych. Związane z nimi niepewności oscylują wokół poszukiwania odpowiedzi na kluczowe pytania dotyczące przyszłości Chin:

1 Szerzej na temat systemów autorytarnych zob. przykładowo: G. O’Donnell, P.C. Schmitter, Transitions from Authoritarian Rule. Tentative Conclusions about Uncertain Democracies, The Woodrow Wilson International Centre for Scholars, The Johns Hopkins University Press, Baltimore 1986. 
jak ten przełomowy politycznie i pokoleniowo moment wpłynie na dalszą modernizację i dotychczas stabilny rozwój państwa; czy nastąpi liberalizacja systemu, czy też może Chiny wkroczą na drogę powrotu do rewolucyjnej epoki; jakie będzie nastawienie kolejnych ekip rządzących do reform; czy utrzymana zostanie stabilność wewnętrzna i wysokie tempo rozwoju gospodarczego, a także czy i w jakim stopniu sytuacja wewnętrzna w Chinach przełoży się na ich intencje w środowisku międzynarodowym? Katalog takich pytań i wątpliwości jest oczywiście szerszy, a ich możliwa liczba tylko odzwierciedla $w$ istocie poziom umocowania i znaczenie Chin na świecie.

Z badawczego punktu widzenia interesujące jest, jak w przypadku ideologicznie komunistycznych, a gospodarczo łączących reformy rynkowe $\mathrm{z}$ zapewnieniem efektywnej kontroli nad nią państwa Chinach przebiega proces przejmowania władzy oraz jakie zjawiska towarzyszą temu w strukturach partii. Dość powszechnie bowiem stosuje się uogólnienia, przedstawiając KPCh i całe Chiny jako monolit, w pełni jednomyślny w prowadzeniu swej polityki. O ile w autorytarnych systemach rządów można uznać, iż kwestia jednomyślności w strukturach władzy teoretycznie nie powinna z oczywistych względów podlegać wątpliwości, o tyle nader często w przypadku Chin - moim zdaniem - w polskich opracowaniach i ekspertyzach poświęca się mało uwagi zjawisku nieformalnej walki frakcyjnej w szeregach KPCh, od której w dużej mierze zależy struktura personalna kierownictwa państwa.

Dla praktyki politycznej ważne jest zrozumienie faktu, że polityka każdej nowej ekipy rządzącej nie może być wyłącznie rozumiana w odniesieniu do przewodniczącego ChRL, wzorem rozwiązań maoistowskich. Jest ona w swym strategicznym i taktycznym wymiarze wynikiem trudnych konsensusów równoważących wpływy grup politycznych interesów, ścierających się w kwestiach pragmatyki urzeczywistniania strategicznych celów i walczących ze sobą o obecne i przyszłe pozycje swych liderów w szeregach KPCh. Istotną sferą oddziaływania i presji na egzekutywę jest również armia chińska z grupami generałów - także „jastrzębi” - starającymi się nadawać ton polityce ChRL, wpływać na bieżące reakcje rządowe, swój budżet i skuteczną realizację założeń doktryny militarnej.

Celem niniejszego opracowania jest podjęcie próby oceny dziesięcioletnich rządów czwartego pokolenia chińskich liderów, analiza bieżącej sytuacji politycznej w Chinach, określenie zasad i kryteriów wyłaniania przez KPCh kolejnych swych przywódców, a następnie sformułowania wizji chińskiej polityki wewnętrznej i zagranicznej w kluczowych jej obszarach za rządów przejmującego władzę kolejnego pokolenia liderów ChRL. 


\section{Synteza osiągnięć rządów Hu Jintao-Wen Jiabao w aspektach politycznym, gospodarczym i społecznym}

Odchodząca w tym roku ekipa liderów chińskich przejęła władzę wraz z wyborem Hu Jintao na Sekretarza Generalnego KPCh podczas rozpoczętego 8 listopada 2002 roku XVI Zjazdu partii, by rok później, w marcu 2003 roku, wybrać go Przewodniczącym ChRL ${ }^{2}$. Nie był on postacią całkowicie nową wśród wyższych kadr partyjnych ${ }^{3}$. Już w 1992 roku został dostrzeżony przez Deng Xiaopinga i włączony do grupy kolejnych chińskich liderów awansem na członka Biura Politycznego KPCh. Pełnione funkcje wiceprzewodniczącego ChRL (od 1998 roku) i wiceprzewodniczącego Centralnej Komisji Wojskowej ChRL oraz Centralnej Komisji Wojskowej KPCh (od 1999 roku) ułatwiły mu drogę kariery politycznej na najwyższy szczebel władzy, którą ostatecznie zakończył, przejmując w marcu 2005 roku od swego poprzednika - Jiang Zemina - stanowisko Przewodniczącego Centralnej Komisji Wojskowej ChRL. Mechanizm przejmowania przez Hu Jintao władzy był podobny jak w przypadku jego poprzednika: przez awanse $\mathrm{w}$ strukturze organizacyjnej KPCh i przejmowanie odpowiedzialności za polityczne i wojskowe decyzje partii i równoległe promowanie w strukturze władzy poprzez stopniowe obejmowanie w niej kolejnych funkcji ${ }^{4}$. Podczas XVI Zjazdu Jiang Zemin i sześciu jego bliskich współpracowników ustąpiło z kierownictwa partii. Wymieniono ponad połowę członków Komitetu Centralnego, w tym trzynastu z dwudziestu jeden członków Biura Politycznego i Stałego Komitetu Biura Politycznego ${ }^{5}$.

Inną kluczową postacią czwartej generacji chińskich liderów jest Wen Jiabao. W 1998 roku został on mianowany przez ówczesnego premiera Zhu Rongji na stanowisko wicepremiera. Stanowisko premiera rządu ChRL przejął w marcu 2003

2 Zgodnie z Konstytucją ChRL z 1982 roku głową państwa jest Przewodniczący ChRL. Zwyczajowo już i ze względów protokolarnych Przewodniczącego ChRL określa się mianem Prezydenta ChRL.

${ }^{3} \mathrm{Hu}$ Jintao pochodzi z rodziny drobnych handlarzy. Jest członkiem partii od 1964 roku. Z wykształcenia jest inżynierem wodnym. Aktywność w Komunistycznej Lidze Młodzieży umożliwiła mu szybko awans w tej strukturze i objęcie funkcji jej przewodniczącego. Następnie w latach 1988-1992 był sekretarzem Komitetu KPCh w Tybecie. W 1989 roku, wobec wybuchu zamieszek antychińskich w Tybecie, $\mathrm{Hu}$ Jintao wprowadził w tym regionie stan wyjątkowy, co pamiętają mu niektórzy chińscy dysydenci. Był zwolennikiem szybkiego stłumienia zamieszek Tybetańczyków przed Igrzyskami Olimpijskimi w 2008 roku i przyspieszenia realizacji rządowego programu osiedlania się Hanów w Tybecie. Nie włada biegle językami obcymi.

${ }_{4}$ Z jednym wyjątkiem. Jiang Zemin zastąpił w czerwcu 1989 roku odsuniętego od władzy Zhou Ziyanga po dramatycznych wydarzeniach na placu Tiananmen.

5 Zob. szerzej: http://fae.pl/raport-fundacji-amicus-europae-chiny-supermocarstwo-xxi-wieku.pdf (26.01.2012). 
roku podczas kolejnej sesji OZPL, tworząc wraz z Hu Jintao duet, który po wyborze 15 marca 2008 roku na drugą kadencję kierował rozwojem Chin przez blisko dekadę $e^{6}$ Wen Jiabao w przeciwieństwie do Hu Jintao, który zyskał w społeczeństwie chińskim opinię przywódcy pozbawionego charyzmy i „figury posągowej”, odznaczył się od początku swego premierostwa niezwykłą pracowitością i zaangażowaniem w rozwiązywanie problemów społecznych, w tym także tych na masową skalę (trzęsienia ziemi, SARS, ptasia grypa, katastrofy górnicze etc.). Duet ten współdzialał zgodnie z podziałem: Hu Jintao, typ technokraty, koncentrował się na polityce zagranicznej, administracji wewnętrznej, sytuacji armii i bezpieczeństwie, Wen Jiabao kierował rządem, gospodarką, odpowiadał za problemy społeczno-polityczne i reformy wewnętrzne.

Przekazywanie władzy w Chinach od 1949 roku odbywa się w tradycji pokoleniowej i na zasadach określanych przez KPCh. Z uwagi na ciągłość utrzymania władzy przez partię oraz niepodważanie jej legitymacji społecznej formalnie nie jest praktykowane tworzenie przez kolejną ekipę tzw. bilansu otwarcia. W wysoce syntetycznej formie i na potrzeby niniejszego opracowania w celu zobrazowania kondycji państwa w aspektach politycznych, gospodarczych i społecznych bilans otwarcia polityki czwartej generacji przywódców chińskich można ująć następująco.

Czwarta generacja przywódców przejęła władzę po ekipie Jiang Zemina w okresie dynamicznego i postępującego wzrostu gospodarczego kraju, wysokiego stopnia stabilności wewnętrznej skutkującego napływem obcego kapitału, jednakże przy istniejących wyzwaniach społecznych i społeczno-politycznych oraz problemach w stosunkach zewnętrznych państwa. Pokolenie to nie wprowadziło rewolucyjnych zmian natury ideologicznej i politycznej, a nadrzędną wytyczną, potwierdzoną podczas XVI Zjazdu partii, stała się kontynuacja reform gospodarczych i polityki modernizacji w oparciu o teorie Deng Xiaopinga i nauki Mao Tse-tunga. Doktrynalną ważność dla nowej ekipy w międzynarodowej aktywności państwa przyjęło sformułowane w 1954 roku pięć zasad pokojowego współistnienia: wzajemnego poszanowania suwerenności i integralności terytorialnej, nieagresji, nieingerencji w sprawy wewnętrzne innych państw, równości i wzajemnych korzyści oraz pokojowej koegzystencji narodów ${ }^{7}$. Tym samym nowi liderzy potwierdzili również niezmienność

6 Wen Jiabao należy do partii od 1965 roku. Z wykształcenia jest inżynierem geologii. Doświadczenia zbierał, będąc dyrektorem biura trzech kolejnych sekretarzy generalnych KPCh. Postrzegany jest w Chinach jako główny ekspert gospodarczy. Wskutek swego głębokiego zaangażowania w rozwiązywanie głównych problemów społecznych w Chinach zyskał wśród społeczeństwa chińskiego poważanie i uznanie jako reformator. Posiada wysokie zaufanie społeczne i partyjne.

7 Zasady te zostały zawarte w preambule chińsko-indyjskiego traktatu w sprawie Tybetu z 29 kwietnia 1954 roku. Istnieją różnice w poglądach, które z tych państw ma większy udział w zdefiniowaniu owych 
dotychczasowego dystansowania się od zachodnich koncepcji i wolę umocowania swej polityki w chińskiej kulturze, historii i ideologii.

$\mathrm{W}$ polityce zagranicznej państwo zwiększało swoje ambicje na drodze dalszego i dynamicznego rozwoju, a dyplomacja chińska coraz pewniej i dojrzalej zachowywała się na arenie międzynarodowej. Ekipa Hu Jintao zachowała paradygmat kontynuacji wypracowanej i wdrożonej do praktyki politycznej w 1996 roku tzw. Wielkiej Strategii Chin (China's Grand Strategie), której generalnym celem jest precyzyjne sterowanie rozwojem Chin w kierunku rozbudowy i udoskonalenia swego statusu $\mathrm{z}$ uwzględnieniem ograniczeń, jakie stwarza unipolarny układ międzynarodowy z hegemonią USA ${ }^{8}$. Nowe wyzwania kreowała potrzeba koncyliacyjnego układania się w stosunkach z USA i UE, rozwiązywania problemów z Japonią i Indiami, pogłębiania relacji z Rosją, a także utrzymania stabilnej sytuacji bezpieczeństwa w najbliższym otoczeniu, w tym w szczególności na Półwyspie Koreańskim.

Sytuacja gospodarcza państwa w chwili przekazywania władzy charakteryzowała się wysoką dynamiką wzrostu gospodarczego. Od 1992 roku przyrost roczny PKB średnio o 8\% doprowadził do dwukrotnego wzrostu wartości nominalnej PKB w 2002 roku. Wysokie tempo rozwoju gospodarczego następowało jednak przy wysokiej nierównowadze jego źródeł, głównie zbyt małego udziału w nim konsumpcji wewnętrznej. Utrzymanie warunków do stałego wzrostu gospodarczego w sytuacji pogłębiającego się strukturalnego niezrównoważenia gospodarki tworzyło wizję zagrożeń, a zarazem wyzwań dla nowych władz.

Rozwarstwienie społeczne na tle ekonomicznym polaryzowało w 2002 roku sytuację ludności miast i wsi, tworząc istotny potencjał rosnących napięć politycznych. Wskazywało na potrzebę wdrożenia polityki pomocy programowej dla najbiedniejszych regionów i zacieśnienia dialogu władza - społeczeństwo na szczeblu prowincji. Korupcja w lokalnych strukturach partii oraz centralnych i regionalnych przedsiębiorstwach państwowych powodująca ekonomiczne straty około $0,5 \%$ rocznego PKB wskazywała na zagrożenie stopniowej degeneracji struktur władzy i partii oraz możliwość ich przekształcania w struktury typu mafijnego ${ }^{9}$. Problemy w zarządza-

reguł (pancha shila), przyjętych i rozwiniętych w 1955 roku w Indonezji przez Ruch Państw Niezaangażowanych na konferencji w Bandungu.

${ }_{8}$ Zob. szerzej: M. Kostrzewa, Stosunki amerykańsko-chińskie jako determinanta bezpieczeństwa w Azji Wschodniej, „Studia i Prace KES” z.n. nr 16, Oficyna Wydawnicza SGH, Warszawa 2008, s. 46.

9 Zgodnie z analizami RAND Corporation. Według innych ekspertów koszty ekonomiczne korupcji w Chinach w latach 1995-1998 sięgały poziomu 13,2-16,8\% rocznego PKB. Statystyki Transparency International wykazują, że w 2000 roku Chiny zajmowały 63. miejsce wśród 90 krajów z najwyższą korupcją. Zob. Ch. Wolf, Jr. et al., Fault Lines In China's Economic Terrain, RAND National Defense Research Institute, Published by RAND, New York 2003. 
niu strukturą administracyjną związane $\mathrm{z}$ wdrażaniem w połowie lat 90. reformy recentralizacji Chin potwierdzały instytucjonalną i kadrową słabość oddziaływania rządu centralnego na szczebel lokalny w ograniczaniu prowadzenia przez władze regionalne polityki wzrostu „za wszelką cenę"10. Brak respektowania praw człowieka przez władze chińskie generował problem o narastającym charakterze zarówno $\mathrm{w}$ wymiarze wewnętrznym, jak i zewnętrznym w stosunkach z głównymi partnerami zagranicznymi. Ochrona własności intelektualnej stawała się coraz poważniejszym wyzwaniem dla władz i szkodziła międzynarodowej reputacji państwa. Narastające trudności w ograniczaniu ich łamania potwierdzały konieczność szybkiego wypełniania przez nowe władze centralne braków legislacyjnych oraz egzekwowania implementacji instrumentów prawnych w tej dziedzinie na szczeblu lokalnym. Ochrona środowiska naturalnego i jego postępująca degradacja wskutek rozwoju ekstensywnej gospodarki rynkowej stawały się palącymi problemami społecznymi i politycznymi, z którymi przyszło się zmierzyć czwartej generacji przywódców przy utrzymaniu dotychczasowego tempa rozwoju gospodarczego kraju ${ }^{11}$.

\subsection{Ewolucja podejścia do reform gospodarczych}

Po przejęciu władzy Hu Jintao rozpoczął sukcesywne ograniczanie wpływów tzw. frakcji szanghajskiej w kierownictwie partii oraz na szczeblu władz lokalnych, umacniając i rozbudowując swoje własne i zaufane kadry. Dominacja frakcji szanghajskiej nad armią i obawy przed wzrostem w niej niezadowolenia umożliwiło dopiero w 2005 roku doprowadzenie do ustąpienia Jiang Zemina ze stanowiska Przewodniczącego Centralnej Komisji Wojskowej ChRL. Hu Jintao nie podważył generalnej linii strategii rozwojowej i priorytetowej roli reform gospodarczych zapoczątkowanych przez Deng Xiaopinga. Natomiast już podczas XVI Zjazdu KPCh wystąpił z inicjatywą ich korekty i silniejszego uwzględnienia w nich czynnika społecznego w celu budowania „harmonijnego społeczeństwa”. Inicjatywa ta wynikała z potrzeby bardziej

10 Program recentralizacji zastąpił zapoczątkowaną w 1978 roku koncepcję decentralizacji polityki gospodarczej w Chinach, która umożliwiła gwałtowny wzrost gospodarczy. Program ten pod nazwą „system kontraktowego finansowania” ( fen zao chi fan - dosł. ,jedzenie w oddzielnych kuchniach”) pozwalał na każdym szczeblu rządowym uzyskiwać oddzielne dochody i równoważyć je własnymi wydatkami. W praktyce oznaczało to wysoką autonomię władz regionalnych w prowadzeniu polityki podatkowej, podczas gdy wysokość uzyskiwanych dochodów była przedmiotem ustaleń pomiędzy rządem centralnym a władzami prowincji.

11 Według danych Chińskiej Państwowej Agencji Ochrony Środowiska w 2003 roku zanieczyszczenie powietrza dwutlenkiem siarki w Chinach skutkowało kosztami około $60 \mathrm{mld}$ dol. poniesionymi na ochronę zdrowia i zabezpieczenie produkcji rolnej. Zob. World Bank and China's State Environmental Protection Administration, Costs of Pollution in China: Economic Estimates of Physical Damages, Beijing 2007 oraz Xiaohua Sun, Pollution Control Targets Not Met, „China Daily” 13.02.2007. 
sprawiedliwej dystrybucji dóbr w społeczeństwie, jaką przynosiło wysokie tempo rozwoju gospodarczego i konieczność niwelowania różnic pomiędzy dochodami ludności miejskiej (w tym biegunów wzrostu gospodarczego - Pekinu i Szanghaju) a ludnością z obszarów wiejskich, żyjącą na granicy ubóstwa ${ }^{12}$. Wskutek osiągnięcia porozumienia w szeregach KPCh inicjatywa ta przełożyła się następnie na powstanie i wdrażanie pod nadzorem Wen Jiabao programów pomocowych dla regionów wiejskich w ramach rozwiązywania tzw. trzech wiejskich problemów (san nong): rolników (nongming), obszarów wiejskich (nongye) i społeczeństw wiejskich (nongcun).

Idea „harmonijnego społeczeństwa” legła u podstaw prac planistów i strategów nad koncepcją polityki zagranicznej ChRL oraz miała stanowić odpowiedź czwartej generacji przywódców chińskich na umacniającą się dominację USA w stosunkach międzynarodowych i utrwalanie się unipolarnego układu sił. Pojawiła się w polityce zagranicznej Chin zasada „multilateralizmu”, a istota tej idei została przetransformowana na stosunki zagraniczne państwa. Po raz pierwszy pojęcie to w retoryce chińskiej pojawiło się w kwietniu 2005 roku na szczycie Azja-Afryka w Dżakarcie. $\mathrm{Na}$ szerszym forum międzynarodowym Hu Jintao zaakcentował je tego samego roku w swym przemówieniu w Nowym Jorku z okazji 60. rocznicy powstania ONZ. Wezwał w nim „narody zjednoczone” do budowy „harmonijnego świata”. Od tego czasu idea ta odwołująca się do pokojowych zamiarów Chin zyskała swój uniwersalizm i koncepcyjne znaczenie aktywności chińskiej w środowisku międzynarodowym ${ }^{13}$.

Wraz z korektą założeń reform gospodarczych i utrzymywania dystansu do reform politycznych nowa generacja chińskich przywódców zdefiniowała w wydanej w 2005 roku corocznej tzw. Białej księdze (White Paper) własną wizję przyszłości kraju. Zgodnie z nią celem strategii rozwojowej Chin jest budowanie „socjalistycznej

12 W Chinach na terenach wiejskich mieszka około 900 mln rolników, którzy nie mają praktycznie żadnych dochodów. Nie mają oni także prawa własności ziemi, którą uprawiają. Zob. S.L. Shirk, China Fragile Superpower, Oxford University Press, Oxford 2007, s. 59-61.

${ }_{13} \mathrm{~W}$ pojęciu tym czytelny jest kontekst amerykański, a implementacja jego do polityki zagranicznej ChRL obliczona jest na uzyskiwanie przez Chiny korzyści politycznych i gospodarczych wszędzie tam, gdzie nie jest aprobowana polityka globalna USA. Według chińskich analityków harmonijny świat spełnia kryteria koncepcji polityki zagranicznej i jest najbardziej znaczącą propozycją zasad organizacji porząaku światowego, wysuniętą przez chińskich przywódców. Natomiast zdaniem ekspertów zachodnich harmonijny świat jest nie w pełni jasnym pojęciem, tworzy raczej ramy dyskusyjne niż zdefiniowaną teorię stosunków międzynarodowych i daje przestrzeń dla jego wypełniania nawet heterogennymi koncepcjami. Bez wątpienia znaczenie tego pojęcia w chińskiej polityce jest przeciwstawieniem się amerykańskiej hegemonii. Zob. O. Brauerner, G. Wacker, Zhou Jiajing, Die 'Harmonische Welt' und Chinas Rolle in Internationalen System, Stiftung Wissenschaft und Politik (SWP), www.swp-berlin.org/de/produkte/ swp-zeitschriftenschau/swp-zeitschriftenschau-detail/article/die_harmonische_welt_und_chinas_rolle_ im_internationalen_system.html 
demokracji z chińską charakterystykąa"14. Cel ten był pochodną sfery polityki gospodarczej i sformułowania w niej wytycznej budowania „socjalistycznej gospodarki rynkowej”. Politycznym tłem dla inicjatyw Hu Jintao wyjaśniających ideologiczne podstawy strategii rozwojowej i reform gospodarczych był wzrost niezadowolenia społecznego w postaci zwiększającej się liczby protestów społecznych w kraju oraz silniejsze naciski na Biuro Polityczne konserwatywnego nurtu w KPCh, które zaczęło oskarżać kierownictwo państwa o odejście od podstawowych zasad partii.

W tym właśnie czasie zaznaczył się wzrost aktywności środowisk intelektualistów, dość odważnie weryfikujących wyniki polityki rządu i wskazujących na negatywnie oddziaływujące na nią czynniki. Prowokowały one do głębszych debat na ten temat w szeregach partii. Obok niezadowolenia konserwatystów ożywienie nastąpiło również po stronie skrajnie lewego skrzydła KPCh wobec podnoszonej krytyki dotyczącej reformy przedsiębiorstw państwowych, dostrzeganej przy tym niesprawiedliwości społecznej i źródła korupcji. Najbardziej popularny w Chinach i osiadły w Hongkongu ekonomista Larry Lang postulował wstrzymanie przez kierownictwo państwa reform. Rząd Hu Jintao-Wen Jiabao stanął w obliczu ostrej krytyki skrajnej lewicy i zbliżonych do niej intelektualistów dotyczącej liberalizacji systemu finansowego (sprzedaży banków chińskich) i wysuwanymi ostrzeżeniami przed utratą ekonomicznej suwerenności Chin. Utrudniło to przyjęcie przygotowanych przez rząd ustaw formalizujących prawo własności prywatnej. Skutkiem tej sytuacji był wzrost w społeczeństwie nacjonalizmu i niezadowolenia z polityki władz. Jej powagę po uchwaleniu jedenastego, pięcioletniego planu gospodarczego w marcu 2006 roku wzmacniały nieoficjalne informacje, iż Wen Jiabao ustąpi ze swego stanowiska, a Hu Jintao poświęci go dla uspokojenia sytuacji w partii i wyznaczy na nowego premiera dotychczasowego ministra handlu Bo Xilaia ${ }^{15}$. W realiach chińskich skrócenie kadencji premiera oznaczałoby wręcz rewolucyjne zmiany na najwyższych szczeblach władz i przyznanie się partii do popełnionych błędów ${ }^{16}$.

14 White paper on political demokracy (full text, „China Daily“ 26.01.2012, www.chinadaily.com.cn/ english/doc/2005-10/19/content_486206.htm

15 Przyjęcie planu nastąpiło podczas czwartej plenarnej sesji dziesiątego Zjazdu Przedstawicieli Ludowych. Z kolei Bo Xilai jest reprezentantem tzw. nowej lewicy, odwołującej się do nauk doktrynalnego marksizmu Mao Tse-tunga, oskarżającej reformatorów o szkody społeczne w szybkich reformach rynkowych. Jest wykształconym na zachodnich uczelniach politykiem, ekspertem gospodarczym. Płynnie włada językiem angielskim.

16 Podczas obrad OZPL Wen Jiabao przyznał w mediach chińskich, że reformy wkroczyły w bardzo trudny etap i odnosząc się do krytyków ze strony skrajnej lewicy, stwierdził, że „cofanie się” nie umożliwia znalezienia drogi wyjścia dla rozwiązania problemów Chin, a reformy muszą być kontynuowane. Zob. CCTV, Wen Jiabao Zongli jizhe zhaodaihui' [konferencja prasowa Wen Jiabao], 14.03.2006, www.cctv.com 
Kolejną cezurą w kontynuowaniu przez duet Hu Jintao-Wen Jiabao polityki wolnorynkowych reform gospodarczych poprzez równoważenie wpływów frakcji partyjnych oraz wychodzenie naprzeciw dyskursom intelektualistów stał się XVII Zjazd KPCh w październiku 2007 roku. Przywódcy chińscy stanęli wówczas przed dylematem, w jaki sposób wzmocnić zasadniczą linię reform i zarazem zyskać aprobatę partii, godząc postulaty lewicy z nacjonalistycznymi resentymentami po prawej stronie $\mathrm{KPCh}^{17}$. Podczas zjazdu partii Hu Jintao zaproponował alternatywną politykę i wezwał kadry partyjne do „emancypacji umysłu” (sixiang jiefang), jako sposobu wspierania jej założeń i celów. Uznając trudności w implementacji reform, wysunął „Koncepcję naukowego rozwoju” ze strategią zawierającą ich kontynuację przy koncentrowaniu się na „czynniku ludzkim” i wykorzystywaniu ku temu osiągnięć nauk społecznych. Dla politycznej oceny tej inicjatywy znaczące jest, iż koncepcja została wymieniona w poprawionym podczas zjazdu statucie partii. Tym samym Hu Jintao potwierdził, że głównym zadaniem partii jest zapewnienie kontynuacji reform $\mathrm{z}$ jednoczesnym dążeniem do bardziej zrównoważonego i trwałego rozwoju.

Wprowadzenie przez Hu Jintao do doktryny politycznej państwa „Koncepcji naukowego rozwoju" faktycznie kumulowało istotę dynamicznych debat prowadzonych również w środowiskach intelektualistów na temat wyboru właściwej przyszłości politycznej i gospodarczej. Przed zjazdem partii wielu z nich artykułowało krytyczne spojrzenie na wiele kluczowych i strategicznych kwestii dotyczących modelu rozwojowego kraju. Podważano zasadność utrzymania trwałego wzrostu gospodarczego i podkreślano potrzebę rozwiązywania problemów gospodarczego otwarcia, zwiększenia przejrzystości zarządzania gospodarką, ograniczania kosztów przemian społecznych oraz większego udziału Chin w sprawach globalnych, świadomie starając się tym samym wpływać na decydentów politycznych oraz debatę wewnętrzną w KPCh. XVII Zjazd partii okazał się być przełomowy w określeniu długofalowej strategii rozwoju gospodarczego Chin. KPCh uznała, że zjazd rozpoczął nowy etap reform zapoczątkowanych 29 lat temu, które powodując negatywne skutki szybkiego wzrostu gospodarczego, przyspieszyły konieczność ponownej oceny teorii Deng Xiaopinga i spowodowały powstanie podstawowych pytań na temat orientacji rozwojowej i natury reform w Chinach $^{18}$.

Wyniki XVII Zjazdu z oceną trzech wcześniejszych dekad reform i wyznaczeniem ich gospodarczych i społecznych celów spowodowały, że w dalszych debatach

17 Nie tylko ideologiczna opozycja kwestionowała linię rządową reform gospodarczych. Po zjeździe partii wicepremier Zeng Peiyan postulował ograniczenie obecności kapitału zagranicznego w strategicznych gałęziach chińskiego przemysłu.

18 C.F. Bergsten et al., China's Rise, Challenges and Opportunities, Peterson Institute for International Economics, Center For Strategic and International Studies, Washington, D.C., 10.2009, s. 36. 
kierownictwa partii oraz wspierających je środowisk naukowych ciężar dyskusji został przesunięty na kwestie przyszłości modernizacji państwa. Odzwierciedleniem takiego podejścia stały się w 2008 roku obchody 30. rocznicy rozpoczęcia reform i polityki otwarcia. W ich trakcie Hu Jintao rozwinął pojęcie „emancypacji umysłu” i wezwał kadry partyjne do rozpoczęcia kampanii edukacyjnej w przełamywaniu „starego myślenia” i właściwej koordynacji wzrostu gospodarczego z rozwojem społecznym. „Emancypacja umysłu” stała się tym samym instrumentem dla implementacji „Koncepcji naukowego rozwoju”, a jednocześnie eksperymentem służącym wdrażaniu reform polityczno-administracyjnych w $\mathrm{Chinach}^{19}$. Miał on na celu nie tylko stymulowanie dyskursu intelektualnego na temat kolejnego etapu rozwoju, lecz przede wszystkim przełamywanie trudności biurokratycznych oraz oporów rządów regionalnych w wykonywaniu dyrektyw rządu centralnego w Pekinie. Dotyczyło to potrzeby kontrolowania na szczeblu lokalnym tempa wzrostu PKB, redukcji zaniedbań i poprawy systemu edukacyjnego, publicznej ochrony zdrowia, środowiska naturalnego, zwalczania ubóstwa, bezrobocia oraz innych negatywnych społecznie skutków szybkiego rozwoju gospodarczego. Służyć temu miały organizowane pod egidą partii liczne spotkania studyjne i sesje naukowe dla urzędników i decydentów lokalnych odpowiadających za implementację polityki centralnej ${ }^{20}$.

\subsection{Reformy polityczne}

Największy deficyt w modernizacji systemowej współczesnych Chin wykazuje bez wątpienia sfera reform politycznych. Jest to jednocześnie najbardziej kontrowersyjna kwestia w ocenach stopnia przemian wewnętrznych w tym państwie, która mimo że nie jest wyraźnie eksponowana w praktyce politycznej, to jest jednak stale obecna jako element dyskusji i badań naukowych. Problem ten stał się nawet celem strategii politycznych definiowanych przez USA, poszukujących optymalnych koncepcji rozwoju stosunków z rozwijającymi się Chinami ${ }^{21}$. Różnice w percepcjach tej kwestii polegają na ocenie ostatecznego celu reform politycznych oraz uznania ich za proces postępującej demokratyzacji. Poprzez pryzmat norm liberalnych demokracji

19 Inicjatywa Hu Jintao nie była oryginalna w historii komunistycznych Chin. Po raz pierwszy w 1978 roku kampania „emancypacja umysłu” służyła Deng Xiaopingowi do przełamania oporu maoistów w zainicjowaniu reform rynkowych. Ponownie wezwanie do przełamywania stereotypów w myśleniu politycznym i strategicznym wykorzystane było przez Deng Xiaopinga w 1992 roku w walce z opozycją partyjną postulującą wstrzymanie reform rynkowych i powrót do gospodarki centralistycznej.

20 C.F. Bergsten et al., op.cit., s. 43.

${ }^{21}$ Dotyczy to tzw. doktryny Clintona, zakładającej rozwijanie stosunków politycznych i gospodarczych z ChRL w celu stymulowania wzrostu klasy średniej w tym państwie, która miała stanowić siłę sprawczą reform politycznych i demokratyzację systemu. Zob. M. Kostrzewa, op.cit., s. 42. 
można zauważyć, iż czynnik systemowy obciąża reformy polityczne w ChRL i sprawia, że partia sprawująca rządy przyjmuje kontrolowane do nich podejście oraz stosując własne metody i sposoby rządzenia, dąży do posiadania własnego stylu demokracji. Wzorce zachodnie uwidaczniają braki w demokratyzacji współczesnych Chin, stając się jednocześnie punktami odniesienia dla formułowanych ocen badawczych i politycznych na najwyższych szczeblach dialogu i współpracy z partnerem chińskim. Istnieją również wątpliwości, czy reformy polityczne w ChRL w ogóle mają miejsce i jaki jest do nich stosunek komunistycznych władz ${ }^{22}$.

W historii ChRL po raz pierwszy zarys planów reform politycznych przedstawił Deng Xiaoping w 1980 roku w swym przemówieniu na forum kierownictwa KPCh. Miały one mieć charakter postępowy wraz rozwojem gospodarczym, być jego naturalnym skutkiem oraz przebiegać pod ścisłym nadzorem kierownictwa partii. Zachowawczy charakter podejścia reformatorów Deng Xiaopinga do reform politycznych krytycznie skonfrontowały wydarzenia na placu Tiananmen w 1989 roku, a nowa ekipa Jiang Zemina po pokonaniu opozycji konserwatystów w KPCh za swój priorytet przyjęła rozwój gospodarczy kraju, praktycznie dezawuując i spychając na dalszy plan znaczenie reform politycznych w debatach partii. Rozpad byłego bloku wschodniego stał się również istotną barierą dla dalszych dyskusji dotyczących systemowego kształtu Chin.

Czwarta generacja przywódców chińskich stanęła więc przed wyzwaniem skonkretyzowania wizji przyszłości politycznej kraju. W 2005 roku w Białej księdze na temat demokracji wskazali oni, że modernizacja Chin prowadzi do „budowy socjalistycznej demokracji z chińską charakterystyką"23. Tym samym podkreślili wolę rozwijania autorytarnego modelu państwa i nieodzowność stopniowego budowania własnego stylu rządów oraz nieakceptowania alternatywnych i radykalnych dla Chin propozycji przemian, jakie mogłaby przynieść implementacja przykładowo tzw. konsensusu waszyngtońskiego ${ }^{24}$. W debatach wewnętrznych KPCh wspieranych opiniami intelektualistów uzyskano wówczas konsensus pomiędzy konserwatywnym a reformatorskim skrzydłem $\mathrm{w}$ określeniu zasadniczej linii przemian ${ }^{25}$. Mają one

22 Takie uwagi artykułują przywódcy USA. Na przykład w 1995 roku prezydent G.W. Bush w trakcie przemówienia w Tokio 15 listopada 2005 roku, w którym wskazał demokrację na Tajwanie jako wzór dla Chin kontynentalnych. Ibidem, s. 6 - przypis 13.

${ }^{23}$ www.china.org.cn/english/2005/Oct/145718.htm (30.01.2012).

${ }^{24}$ Konsensus waszyngtoński jest 10-punktową strategią rozwoju gospodarczego i politycznego, która pozwoliła po II wojnie światowej przy aktywnym udziale USA na powstanie międzynarodowych instytucji wspierających neoliberalne i neoklasyczne gospodarki. Chiny wypracowały własny model, tzw. konsensus pekiński, alternatywny wobec demokracji wolnorynkowych. Zob. szerzej S. Haller, The Beijing Consensus, How China's Autorytarian Model Will Dominate The Twenty-First Century, Basic Books, New York 2010.

$25 \mathrm{~W}$ niniejszym opracowaniu na określenie frakcji i grup politycznego wpływu w KPCh przyjęto kryterium ich stosunku do reform ekonomicznych. 
prowadzić do budowania swoistego modelu rządów (xieshang minzu), który selektywnie zapożycza elementy $z$ innych demokratycznych systemów i opiera się na utrzymaniu kierowniczej roli partii, większym udziale społeczeństwa w procesach politycznych, kierowaniu państwem zgodnie z zasadami prawa, przy jednoczesnym odrzuceniu powszechnego prawa wyborczego, wielopartyjnych wyborów oraz struktur parlamentarnych pochodzących z wolnych wyborów ${ }^{26}$.

Przy tak określonym celu przemian politycznych Hu Jintao zdołał utrzymać podstawową linię reform zapoczątkowanych przez Deng Xiaopinga i stonował krytykę w partii akcentowaną przez oba jej radykalne skrzydła. Wskutek przemyślanej przez niego podczas XVII Zjazdu partii w 2007 roku restytucji aktualności i utrzymania podstawowego znaczenia dla procesu modernizacji Chin tzw. czterech kardynalnych zasad, tj. utrzymania socjalistycznej drogi przemian, demokratycznej władzy ludu, kierowniczej roli KPCh, rozwoju zgodnie z naukami Marksa-Lenina i Mao Tse-tunga, stworzył on akceptowalne dla partyjnych frakcji ideologiczne ramy dla wizji reform politycznych. Ich socjalistyczna podbudowa w połączeniu z istotą „Koncepcji naukowego rozwoju" pozwoliła mu na przekonanie konserwatywnego obozu, że reformy gospodarcze poprzedzają reformy polityczne, które pozostaną pod pełną kontrolą KPCh. Reformatorska frakcja została jednocześnie zapewniona o nieodwracalności przemian rynkowych i polityki gospodarczego otwarcia jako centralnego zadania partii, która utrzymuje przy tym swe podstawowe ideologiczne zasady ${ }^{27}$.

Wzmocnienie przez ekipę Hu Jintao-Wen Jiabao junctim pomiędzy kwestią reform gospodarczych a problemem reform politycznych i zyskanie na to akceptacji partyjnej pozwoliło z kolei na podjęcie inicjatywy wyjaśniającej charakter definiowanej drogi i tempa modernizacji Chin. Podczas XVII Zjazdu partii Hu Jintao silnie zaakcentował wprowadzoną do polityki zagranicznej Chin w 2005 roku jej nową podstawę - zasadę tzw. pokojowego rozwoju, która dla środowiska międzynarodowego miała również obrazować właściwe intencje w globalnej aktywności Chin w XXI wieku. Inicjatywa ta miała wychodzić naprzeciw podnoszonym w państwach demokratycznych obawom przed niejasnym kierunkiem ujścia wzrastającego potencjału gospodarczego, modernizacji armii, umacniających się w układzie światowym Chin.

Niektórzy eksperci zachodni analizując fenomen politycznych reform w Chinach, charakteryzują je jako instrumentalne, progresywne i specyficzne (instrumental, incremental, idiosyncratic) ${ }^{28}$. Specyfikę tę uwidoczniło podejście ekipy Hu Jintao-Wen Jiabao do uzyskania postępu w debatach nad politycznymi przemianami. Ich instrumentalizm polega na zachowaniu przez KPCh kluczowej roli nad przebiegiem

26 Za: C.F. Bergsten et al., op.cit., s. 57.

27 Ibidem, s. 34.

28 Ibidem, s. 58. 
i kontrolą zakresu reform politycznych, a budowanie socjalizmu z chińską charakterystyką służyć ma propagandowemu wyjściu naprzeciw wyzwaniom, jakie powoduje proces modernizacji w wymiarze społecznym i społeczno-ekonomicznym. Progresywny charakter politycznych reform ma za zadanie wytworzyć społeczne przekonanie o ich ważności i priorytetowym znaczeniu dla KPCh, również dla wewnętrznej demokratyzacji partii (dangnei minzu), przy zachowaniu ich ewolucyjnej, a nie rewolucyjnej postaci. Na specyfikę chińskiego spojrzenia na problem reform politycznych składają się aprobowane przez władze tezy, iż w semantyce ideologicznej i politycznej demokracja nie zawiera w sobie systemowego uniwersalizmu. W przypadku Chin „optymalizacja” jej kształtu powinna być wypadkową zasad pochodzących z teorii marksizmu, rozwiązań zachodnich oraz chińskiej szkoły myślenia i być dostosowana do społeczno-politycznych uwarunkowań i poziomu zaawansowania rozwoju gospodarczego kraju.

Znaczna część założeń reform sformułowanych podczas zjazdu przez ekipę Hu Jintao-Wen Jiabao napotkała trudności implementacyjne na szczeblu lokalnym, gdzie większe otwarcie na społeczny udział w decyzjach politycznych oraz tzw. demokracja z udziałem zwykłych ludzi (grass-roots democracy) nie były akceptowane przez rządy regionalne prowadzące nadal własną politykę szybkich korzyści finansowych w procesach urbanizacji i industrializacji. Towarzyszyła temu endemiczna korupcja, będąca jednym z kluczowych na tym szczeblu stymulatorów rozwoju gospodarczego. Spektrum protestów obejmowało rolników sprzeciwiających się lokalnym urzędnikom konfiskującym im ziemię i płacącym za to symboliczne odszkodowania, właścicieli domów przeciwko ich burzeniu pod nową architekturę, kierowców przeciwko rosnącym cenom benzyny, środowisk akademickich z postulatami ochrony środowiska naturalnego i ochrony produktów spożywczych ${ }^{29}$.

Dyrektywami centralnymi wdrożono pewne „eksperymenty” wprowadzania „socjalistycznej demokracji” na szczeblach prowincji. W pionierskiej modernizacji prowincji Guandgdong, z wolną strefą ekonomiczną w Shenzen, założenia rządowe przewidują utworzenie „specjalnej politycznej strefy” z demokracją wewnątrzpartyjną wspieraną demokracją oddolną, włącznie z bezpośrednimi wyborami deputowanych na lokalny zjazd partii i większościowymi wyborami. Z kolei inne próby wprowadzania na szczeblu prowincji demokratycznych zasad są nadal w trakcie realizacji i napotykają urzędniczy opór lokalnych decydentów i skorumpowanych aparatczyków

29 Według danych zachodnich w 2005 roku doszło w Chinach do 87 tys. protestów społecznych. W ocenach Chińskiej Akademii Nauk Społecznych w 2006 roku liczba ta wyniosła ponad 90 tys. incydentów. Pomimo braku oficjalnych i wiarygodnych danych chińscy naukowcy szacują, że w 2010 roku niezadowolenie społeczne mogło wywołać około 180 tys. zamieszek i incydentów. Zob. http://articles. latimes.com/2011/oct/08/world/la-fg-china-protests-20111009 (30.01.2012). 
niezamierzających akceptować wytycznych rządu centralnego i odpowiadać zdecydowanie na działania „świadomej prawicy” na obszarach wiejskich. W prowincji Zhejang wdrożony został program demokratycznych konsultacji, w ramach którego obywatele mogą zadawać pytania lokalnym władzom i formułować opinie dotyczące ważnych kwestii ich polityki. W prowincji Sichuan dozwolone jest wyznaczanie niepartyjnych kandydatów do wyborów okręgowych ${ }^{30}$.

\section{Sytuacja w Komunistycznej Partii Chin przed XVIII Zjazdem}

KPCh jest obecnie największą partią polityczną w świecie, liczącą według danych za 2010 rok ponad $80 \mathrm{mln}$ członków ${ }^{31}$. Sytuacja wewnętrzna w partii charakteryzuje się występowaniem w niej kilku podziałów o podłożu ideologiczno-programowym, regionalnym i organizacyjnym, które obejmując również prominentów w kierownictwie państwa, tworzą nieformalne frakcje i grupy politycznego wpływu. Łączą je niekwestionowane ogólne zasady utrzymania socjalistycznej drogi rozwojowej, „pozostawienia władzy w rękach ludu”, utrzymanie kierowniczej roli partii i odniesienie w rozwoju do nauk Marksa, Lenina i Mao Tse-tunga. Tradycyjna i ukształtowana historycznie jest oś podziału, jaką tworzy kwestia stosunku do modernizacji, która dzieli środowisko partyjne na obóz reformatorów i konserwatystów. W przypadku Chin zróżnicowanie następuje na podstawie mieszanych kryteriów mieszczących się w ramach określanych przez państwo, partię komunistyczną i nacjonalizm.

Reformatorzy akceptują linię modernizacji Chin zgodnie z reformami zapoczątkowanymi przez Deng Xiaopinga. Konserwatyści opowiadają się za modernizacją poprzez rozwój gospodarczy z centralnym planowaniem i jedynie inkorporowaniem do niego niektórych regulacji wolnorynkowych. W centrum swej uwagi stawiają oni koszty społeczne, jakie powodują dynamiczne reformy, i postulują większą sprawiedliwość społeczną w podziale dóbr, które przynosi wzrost gospodarczy.

\section{- „Stara lewica”}

W konserwatywnym nurcie KPCh odłam o utrwalonych tradycjach, który sprzeciwia się reformom rynkowym i gospodarczemu otwarciu Chin na świat. Tworzą go starsi członkowie partii i związani z nimi intelektualiści, z których najważniejsi to: Li Peng, Chen Yun, Hu Qiaomu, Wang Zhen, Deng Liqun, Gao Di, Yu Quanyu,

C.F. Bergsten et al., op.cit., s. 64-65.

$31 \mathrm{Na}$ podstawie danych podawanych przez Departament Organizacyjny KPCh, http://www. chinatoday.com/org/cpc/ (15.02.2012), a także zob. szerzej: Xie Chuntao, Why and how the CPC works in China, New World Press, Beijing, China 2011. 
Liu Guogang. Ich poglądy ogniskują się wokół norm dogmatycznego marksizmu i nauk Konfucjusza. Grupa ta jest ideologicznie wspierana przez naukowców skupionych w Instytucie Badań Marksizmu w Chińskiej Akademii Nauk Społecznych w Pekinie, takich jak: Chen Kuiyan, Hang Quanjing, Li Shenming, Liu Fengyan, Zhang Shuhua ${ }^{32}$.

\section{- „Nowa lewica”}

Najmłodszy i wzmacniający się nurt myśli politycznej wśród chińskich intelektualistów, który wykrystalizował w latach 90. na bazie krytyki reform rynkowych, w tym krytyki reformy przedsiębiorstw państwowych skutkującej endemiczną korupcją. Jej przedstawiciele postulują rozwój reform gospodarki rynkowej pod ścisłym kierownictwem partii, której zadaniem jest dostosowanie tempa reform do rozwoju społecznego i minimalizowanie kosztów społecznych reform. Obóz ten, mający oparcie w KPCh, wysuwa oskarżenia pod adresem Deng Xiaopinga i Jiang Zemina o zbyt szybkie tempo reform, które doprowadziły do obecnych problemów społecznych. Najbardziej znani przedstawiciele tego nurtu to: Wang Hui oraz Cui Zhiyuan. Popierają oni badanie własnej drogi rozwojowej dla Chin jako alternatywy dla modelu zachodniego. Część tej grupy intelektualistów jest zainteresowana kwestiami reform obszarów wiejskich. W swych ideologicznych postulatach zbliżeni są do międzynarodowej krytyki globalizacji i neokolonializmu. Krytykują finansową liberalizację w Chinach i wchodzenie obcego kapitału w strategiczne gałęzie gospodarki oraz do sektora bankowego, ostrzegają przed utratą gospodarczej niezależności oraz sprzeciwiają się reformie przedsiębiorstw państwowych.

Na powyższy społeczny i partyjny podział nakłada się jeszcze inne zróżnicowanie - związane z kryteriami rozwoju kariery partyjnej i rządowej, co skutkuje tworzeniem grup wpływu skupionymi wokół przywódców chińskich. W tym podziale można wyróżnić wymienione niżej frakcje.

\section{- „Frakcja szanghajska” (Shanghaibang)}

Jest grupą regionalną, która wytworzyła się z kadr wysokich działaczy partyjnych administracji rządowej Szanghaju i sąsiednich prowincji na wschodnim wybrzeżu, w tym również podwładnych Jiang Zemina (w latach 1985-1889 gubernatora, a następnie sekretarza KPCh w Szanghaju). Po przejęciu przez niego władzy w 1992 roku frakcja ta stała się najbardziej wpływową grupą w najwyższych organach

32 Instytut ten postał w 2005 roku na mocy dyrektywy rządowej zwiększającej nakłady budżetowe na badanie marksizmu i leninizmu oraz maoizmu. Jego kadry były zaangażowane w przygotowanie programu nagranego i rozpowszechnionego na DVD, w którym oskarżono Nikitę Chruszczowa i Michaiła Gorbaczowa o popełnienie ideologicznych błędów skutkujących upadkiem ZSRR. W kręgach politycznych i naukowych w Chinach program ten postrzegano jako zawoalowaną krytykę Jiang Zemina i Hu Jintao. Zob. C.F. Bergsten et al., op.cit., s. 53. 
KPCh. Awanse w strukturach władz jej przedstawiciele zawdzięczają w mniejszym stopniu aktywności w partii, w większym zaś mało czytelnym układom oraz koneksjom biznesowym w lokalnych środowiskach. Stąd określenie tej grupy, które ma pejoratywne znaczenie i potocznie odnosi się do kwestii korupcji w Chinach. Do czołowych przedstawicieli tej frakcji należą: Zeng Qinghong, Wu Bangguo, Huang Ju, Jiang Chunyun, Jia Qinglin. Hu Jintao po ustąpieniu swego poprzednika w 2005 roku z przewodniczenia Centralnej Komisji Wojskowej ChRL rozpoczął stopniowe ograniczanie wpływów tej grupy w strukturze rządu centralnego i Biura Politycznego KPCh. Z tej grupy wywodzi się aresztowany w 2006 roku za malwersacje finansowe i łapówki burmistrz i sekretarz KPCh w Szanghaju Chen Liangyu ${ }^{33}$.

- „Elita Ligi Młodzieży” (Tuanpai)

Jest to grupa, która powstała na bazie organizacyjnej struktury partii i skupia obecnie wokół Hu Jintao działaczy wykształconych ideologicznie w Komunistycznej Lidze Młodzieży oraz Federacji Chińskiej Młodzieży. Silna i najbardziej wpływowa frakcja w KPCh. Tworzą ją niepowiązani bezpośrednio z biznesem funkcjonariusze partyjni, wyrośli w szkołach partyjnych, gotowi uznawać nadrzędność ideologicznych wartości i norm przemian systemowych nad wymiernymi korzyściami, które przynosi polityka otwarcia i gospodarczej modernizacji. Są to zazwyczaj eksperci do spraw ideologicznych i modernizacji marksizmu, propagandy oraz kwestii dyscyplinarnych i personalnych. Grupa ta jest słabo reprezentowana na szczeblach dowódczych w armii chińskiej. Czołowymi przedstawicielami tej grupy są: Li Keqiang, Li Yuanhao, Wanh Yang, Liu Yandong, Ling Sinhua.

- „Grupa książąt”” (Gaoganzidi)

Jest najmłodszą grupą politycznego wpływu powiązaną koneksjami rodzinnymi i biznesowymi z „Frakcją szanghajską”. Nie tworzy ona klasycznej frakcji w KPCh, jest raczej politycznym blokiem z poparciem w szeregach partii, administracji centralnej i regionalnej, armii, państwowego sektora energetycznego. Szczególnie na szczeblu dowódczym i politycznym w armii grupa ta jest wyraźnie reprezentowana ${ }^{34}$. Ze względu na swój rosnący potencjał polityczny i elitarność określana jest także jako „partia książąt”. Jej przedstawiciele posiadają świadomość grupową i kolektywną tożsamość. W jej skład wchodzą potomkowie starszego pokolenia rewolucjonistów epoki Mao Tse-tunga, którzy dostosowują się do zaleceń

\footnotetext{
${ }^{33}$ Jiang Zemin, Huang Ju i Chen Liangyu (ten ostatni zastąpił Hanga na stanowisku sekretarza partii w Szanghaju) tworzyli tzw. żelazny trójkąt.

34 W 2009 roku nominacje generalskie w armii chińskiej otrzymało trzech potomków weteranów „wojny wyzwoleńczej”: Liu Yuan, polityczny komisarz w Chińskiej Akademii Wojskowej w Pekinie, Zhang Haiyang, polityczny komisarz II Korpusu Artylerii oraz Strategicznych Sił Rakietowych i Ma Xiaotian, zastępca szefa departamentu w Sztabie Generalnym.
} 
Deng Xiaopinga z połowy lat 70., by nie wprowadzać swych dzieci na ścieżkę kariery partyjnej, a korzystać z polityki otwarcia Chin na świat i możliwości biznesowych. Są to beneficjenci wzrostu gospodarczego o obecnie rozbudowywanych politycznych koneksjach. Wielu z nich zdobywało wykształcenie na Zachodzie i włada obcymi językami. Posiadają wpływy w chińskich i międzynarodowych kołach biznesowych. Grupa ta ma istotny polityczny potencjał i stała się - wspierana przez „Frakcję szanghajską” i Jiang Zemina - głównym konkurentem „Elity Ligi Młodzieży” w walce o władzę. Sygnałem restytucji wpływów 73-letniego Jiang Zemina i ich konsolidowania się z Xi Jinpingiem w walce o władzę w partii w 2012 roku było jego nieoczekiwane pojawienie się w pierwszej linii obok Hu Jintao na paradzie wojskowej w 2009 roku z okazji 60. rocznicy powstania ChRL. Niektórzy prominentni przedstawiciele tej grupy otwarcie wzywają do restytucji maoizmu i innych socjalistycznych norm ${ }^{35}$. W warstwie ideologicznej zbliżeni są do „Nowej lewicy". Głównymi jej reprezentantami są: Xi Jinping, były sekretarz partii w Szanghaju i w Zhejiangu, obecnie wiceprzewodniczący i kandydat na przewodniczącego ChRL, Bo Xilai, sekretarz partii w Chongqing, gen. Liu Yuan, zastępca Politycznego Komisarza Departamentu Generalnej Logistyki Chińskiej Armii Narodowo-Wyzwoleńczej, Wang Shang, burmistrz Pekinu, który przeszedł z „Elity Ligi Młodzieży” do "Grupy książąt".

\section{- „Reemigranci” (Haiquipai)}

Jest to grupa społeczna niereprezentowana $\mathrm{w}$ strukturach kierowniczych KPCh. Służy kierownictwu partii do poszukiwania nowych kadr i kandydatów do władz ${ }^{36}$. Grupa ta posiada swych przedstawicieli na wyższych szczeblach administracji państwowej, w sektorze finansów, nauki i technologii, handlu. Są to osoby, które z różnych powodów, aczkolwiek legalnie i za zgodą władz, wyjechały z Chin, a często korzystając z fundowanych stypendiów, ukończyły renomowane uczelnie w USA, Japonii, w Europie, specjaliści z wyższymi stopniami naukowymi z dziedziny techniki, nauk ścisłych, ekonomii, zrządzania etc. Szacuje się, że obecnie grupa ta liczy około 300 tys. osób. Środowisko to jest zbliżone do nurtu technokratycznego. Polityczną funkcją tej grupy w mechanizmach przejmowania władzy

35 Najbardziej jaskrawym przypadkiem była aktywność Bo Xilaia, który od 2007 roku prowadził w Chongqing aktywną kampanię popularyzującą kult Mao Tse-tunga, doktrynę „,rewolucji kulturalnej”. $\mathrm{W}$ tej prowincji stawiane były nowe pomniki Mao. Aktywność ideologiczna Bo Xilaia w prowincji mała wzrastający charakter. Prowadziła do pogłębienia niezadowolenia najuboższych środowisk i powodowała artykułowanie ocen o zdradę przez Hu Jintao i Wen Jiabao ideałów rewolucji. Zob. „Apple Daily” 12.11.2009 oraz Bo Xilai says there are good reasons for popularizing 'red songs', „China News Service” 20.04.2010.

36 W 2009 roku KPCh zainaugurowała nową kampanię medialną pn. „Program Tysiąca Talentów” w celu wyłaniania najbardziej kwalifikowanych, wykształconych za granicą Chińczyków i zachęcania ich do pracy w strukturach partii i rządu. 
jest stwarzanie możliwości równoważenia w składzie przyszłego Stałego Komitetu Biura Politycznego KPCh wpływów dwóch najsilniejszych frakcji w partii. Z grupy tej korzystał świadomie już Hu Jintao w 2002 roku, dobierając z niej niektórych ministrów. Nie było to jednak zjawisko na tyle szerokie, by można stosować uogólnienie, iż czwarta generacja przywódców chińskich to ekipa technokratów ${ }^{37}$. Przeczy temu statystyka, znajomość preferencji Hu Jintao oraz międzygeneracyjna istota modelu transferu władzy.

\section{- „Technokraci”}

Jest to luźna grupa interesu, silnie zindywidualizowana, niestała w swych preferencjach dotyczących przynależności lub poparcia głównych frakcji w KPCh, zawdzięczająca swą pozycję rozwojowi gospodarczemu, w tym strategicznym sektorom gospodarki. Tworzą ją szefowie i menedżerowie kontrolowanych przez państwo kluczowych przedsiębiorstw i koncernów, którzy funkcjonują i korzystają z sieci posiadanych przez siebie koneksji (guanxi) na najwyższych szczeblach partii i rządu. Znaczna część z nich posiada wykształcenie inżynierskie lub naukowe zdobyte na zachodnich uczelniach. Z uwagi na swój wiek (40-50 lat) postrzegani są jako baza kandydatów na szóstą generację przywódców chińskich. Głównymi reprezentantami tej grupy są: Su Shulin prezydent SINOPEC, Zhang Qingwei, dyrektor COMAC (Chińska Korporacja Przemysłu Lotniczego), Zhu Yangfeng, współtwórca chińskiego przemysłu samochodowego. Wszyscy oni są niestałymi członkami KC KPCh.

\section{Piąta i szósta generacja przywódców Chin. Kryteria doboru}

W historii Chińskiej Republiki Ludowej przekazywanie władzy kolejnemu pokoleniu przywódców było zawsze ważnym momentem, który generował dwa zasadnicze pytania:

- Czy proces ten przebiegnie pokojowo i nie spowoduje destabilizacji sytuacji wewnętrznej w kraju z zagrożeniem wystąpienia negatywnych dla społeczności międzynarodowej implikacji w polityce zagranicznej?

$37 \mathrm{~W}$ rankingu 13 najważniejszych przedstawicieli czwartej generacji do grupy technokratów zalicza się jedynie $5 \mathrm{z}$ nich: premier Wen Jiabao, wicepremier Wu Yi (emerytowana w 2008 roku), prezydent Chińskiej Politechniki w Pekinie Zhou Ji, sekretarz KPCh w Tianjinie Zhang Gaoli, sekretarz generalny Rady Państwowej ChRL Ma Kai. Por. http://www.polityka.pl/swiat/ludzie/1511712,1,xi-jinping-nastepca-hu.read (10.02.2012). 
- Czy przejmujący władzę będą kontynuować dzieło swych poprzedników w modernizacji systemowej i gospodarczej, czy też spowodują odejście od wolnorynkowych reform i obiorą inny kurs rozwojowy?

W systemach autorytarnych kwestia przekazywania władzy niezmiennie łączy się z czynnikiem zagrożenia bezpieczeństwa dla powstającego nowego układu rządów, w którym źródło władzy nie wynika $\mathrm{z}$ udziału większości społeczeństwa, a z innych, narzucanych przez rządzących rozwiązań. W przypadku Chin w analizach problemu, czy przejmowanie władzy przez piątą generację przywódców chińskich będzie procesem bezpiecznym, wydaje się, że należy się skoncentrować na następujących aspektach:

- Jakie są dotychczasowe doświadczenia z funkcjonowania modelu przekazywania władzy z przeszłości?

- Czy istniejące w KPCh silne podziały frakcyjne są zdolne w konfrontacji o władzę wyjść poza ramy tego mechanizmu? Innymi słowy, czy podziały frakcyjne są również wynikiem braku zgody co do generalnej strategii i celów rozwojowych kraju?

- Czy występują obecnie przesłanki mogące wskazywać na to, że armia chińska może wypowiedzieć posłuszeństwo nowo wybranym władzom i sama przejąć kontrolę nad transferem władzy?

- Czy istnieje zagrożenie ingerencji wewnętrznej (ze strony społeczeństwa) lub zewnętrznej (z za granicy) w proces przekazywania władzy?

W kwestii oceny bezpieczeństwa chińskiego modelu przekazywania władzy należy podkreślić, iż został on zapoczątkowany przez Deng Xiaopinga i opiera się na zasadzie wyłaniania przez ustępującą generację liderów kandydatów na ich następców na dwie generacje na podstawie kryteriów personalno-partyjno-ideologicznych poprzez stopniową ich promocję w hierarchii partyjnej i rządowej. Etapowość promocji polega na mianowaniu wytypowanych kandydatów na członków Biura Politycznego KPCh lub obsadzeniu stanowisk sekretarzy partii w ważniejszych prowincjach podczas zjazdu poprzedzającego zjazd, w trakcie którego ma nastąpić przekazanie władzy. Proces promowania trwa więc dekadę i obejmuje dwa kolejne zjazdy partii. Z politycznego względu jest to system nacechowany względną transparentnością i ograniczający czynnik niepewności lub nieprzewidywalności decyzji, gdyż pięć lat przed przejęciem władzy przez kolejną generację wiadome jest, kto został „nominowany” na kolejnego przewodniczącego ChRL i kto ma szansę na wejście do struktury przyszłych władz.

$\mathrm{W}$ aspekcie bezpieczeństwa tego modelu istotny jest również fakt, że przekazanie władzy w 2002 roku przez ekipę Jiang Zemina dla generacji Hu Jintao przebiegło najbardziej płynnie w całej historii ChRL i bez politycznych napięć. Nastąpiło to przy istnieniu pomiędzy głównymi frakcjami w KPCh szerokiego konsensusu w kwestii 
narodowych celów i strategii rozwojowej zakładającej budowę socjalizmu z chińską charakterystyką. W związku z tym można zakładać, że konfrontacja frakcyjna przed XVIII Zjazdem będzie raczej prowadzona wewnątrz partii i koncentrować się będzie na uzyskaniu jak największej liczby reprezentantów w strukturach Biura Politycznego, w tym Stałego Komitetu oraz obsadzeniu sekretarzy partii w znaczących prowincjach. Pomimo istniejących różnić natury programowej partia prezentuje po czerwcu 1989 roku dość wysoki stopień jednomyślności i zgodności poglądów odnośnie ochrony ideologicznych i politycznych interesów Chin $^{38}$.

Chińska Armia Ludowo-Wyzwoleńcza (PLA) jest ściśle podporządkowana centralnym władzom chińskim, a jej zwierzchnikiem jest Przewodniczący ChRL, będący jednocześnie Przewodniczącym Centralnej Komisji Wojskowej ChRL. Wszyscy członkowie Sztabu Generalnego PLA należą do partii. W kręgach wyższych dowódców wojskowych i generałów zdecydowane większe wpływy mają grupy skupione wokół Jiang Zemina. Jak dotąd, nawet podczas tragicznych wydarzeń na placu Tiananmen nie doszło do wypowiedzenia posłuszeństwa armii urzędującym władzom. W okresie swych dwóch kadencji Hu Jintao podniósł uposażenie w armii ponad dwukrotnie, przy jednoczesnym kontynuowaniu intensywnego procesu modernizacji chińskich sił zbrojnych i stałym zwiększaniu rocznego budżetu na zbrojenia do obecnego poziomu (ponad $100 \mathrm{mld}$ dol.). Nie ma obecnie widocznych przesłanek politycznych, finansowych, które mogłyby wskazywać, że dowództwo armii chińskiej może nie zaakceptować nowych władz partii. Armia z uwagi na najsilniejsze w niej wpływy „Grupy książąt” raczej z zadowoleniem przyjmie fakt większej reprezentacji w nowych władzach tej frakcji wraz z pochodzącym z niej Xi Jinpingiem, nowym Przewodniczącym Centralnej Komisji Wojskowej KPCh i przyszłym Przewodniczącym ChRL. Podobnie mało prawdopodobne jest, aby mogło dojść do jakiejkolwiek bezprecedensowej próby ingerencji zewnętrznej w proces przekazywania władzy w Chinach. Możliwe w tym czasie protesty społeczne o podłożu ekonomicznym czy też separatystycznym raczej nie osiągną potencjału zdolnego zakłócić lub zmienić kierunek procesu wyboru piątej generacji przywódców.

Identyfikując kryteria doboru kandydatów do kolejnych elit, piątej i szóstej generacji przywódców, należy zwrócić uwagę na istotę ich interesów i charakterystykę podziałów frakcyjnych w KPCh. Z tego względu niewątpliwe jest to, że Hu Jintao z ciągle silną „Elitą Ligi Młodzieży” w rywalizacji z powiększającą swe wpływy „Grupą książąt” będzie preferował wartości ideologiczne i przywiązanie do partii. W konfrontacji z profesjonalnym profilem reprezentantów „Grupy książąt”, posiadających

38 Do tych interesów należy zaliczyć: walkę z secesjonizmem w Tybecie, Hongkongu, Xinjiangu i na Tajwanie, utrzymanie przez partię władzy, zwalczanie dysydentów i przeciwników systemu, ochronę interesów liderów kierownictwa państwa, utrzymanie socjalistycznej drogi rozwojowej. 
w swych szeregach menedżerów, znających realia świata biznesmenów, nie będzie miał on innego wyboru, jak oprzeć się na „moralności” dotychczasowych urzędników partyjnych, którzy w różnych układach znaleźli się we władzach centralnych i regionalnych strukturach partii ${ }^{39}$. Tego rodzaju podejście ogranicza przestrzeń dla liberalizacji systemu, ewentualnego pojawienia się „chińskiego Gorbaczowa” oraz utratę w partii uprzywilejowanej pozycji „Elity Ligi Młodzieży”, na co wyraźnie nie wyrażają zgody obecnie ustępujący liderzy z Hu Jintao na czele ${ }^{40}$.

Pomimo wysokiej przewidywalności procesu transferu władzy i jej przyszłych struktur powstaje pytanie, dlaczego dochodzi do sytuacji, że odchodzący Przewodniczący ChRL nie zapewni niejako przez „aklamację” sobie następcy z tej samej frakcji lub grupy zaufanych popleczników, tak jak np. po Jiang Zeminie władzę przejął niefaworyzowany przez niego Hu Jintao, który z kolei obecnie przekaże władzę w partii $\mathrm{Xi} \mathrm{Jinpingowi,} \mathrm{a} \mathrm{nie} \mathrm{Li} \mathrm{Keqiangowi}{ }^{41}$ ? Otóż istotną rolę w procesie wyboru kolejnego przewodniczącego partii i szefa rządu odgrywa to, jaką pozycję w hierarchii ważności zajmuje on w strukturze Stałego Komitetu Biura Politycznego KPCh. Jeżeli wyżej notowani od niego członkowie Stałego Komitetu przestają pełnić swe funkcje, jest on naturalnym kandydatem do zostania numerem jeden w partii i państwie. Z obecnych dziewięciu członków Stałego Komitetu w listopadzie 2012 roku odejdzie siedmiu, z uwagi na osiągnięcie wieku emerytalnego. Pozostanie zajmujący szóstą pozycję Xi Jinping (wiceprzewodniczący ChRL, wiceprzewodniczący Centralnej Komisji Wojskowej ChRL) oraz siódmy w rankingu Li Keqiang. Stąd też mechanizm przejmowania władzy wysuwa Xi Jinpinga na szefa partii i głowę państwa.

39 Wyraźnie wskazuje na to obecna popularność w otoczeniu Hu Jintao i jego protegowanych słowa „de” oznaczającego „moralność". Z kolei z kilku wypowiedzi Xi Jinpinga dotyczących przyszłości partii i jej kadr wynika, że obok kwestii moralności akcentuje on równolegle słowo „cai” oznaczające „profesjonalne kompetencje", co wspólnie może stanowić motto funkcjonowania piątej generacji przywódców i kryterium wyboru z partii przedstawicieli szóstej generacji przywódców. Sugeruje to, że Xi Jinping jest kontynuatorem spojrzenia Jiang Zemina na określanie wartości i przydatności wyższych kadr partyjnych do sprawowania władzy.

${ }_{40}$ China's liberals..., op.cit. W artykule Hu Jintao stwierdził, że „wrogie siły z zagranicy konspiracyjnie aktywizują się, aby narzucić nam zachodnią kulturę i nas podzielić". Było to odniesienie do publikowania w internecie w grudniu 2011 roku i styczniu 2012 roku przez trzech Chińczyków „dysydentów” - Chen Wei, Chen Xi i Li Tie - artykułów nawołujących do bezprzemocowej politycznej liberalizacji Chin. Zostali oni aresztowani i skazani na kary od dziewięciu do dziesięciu lat więzienia za „podjudzanie do obalenia rządu".

41 Deng Xiaoping zaskoczył Jiang Zemina promowaniem w 1992 roku wówczas 49-letniego Hu Jintao, sekretarza partii w Tybecie, do Biura Politycznego KPCh, określając go wtedy jako filar czwartej generacji przywódców chińskich. Z kolei Jiang Zemin zastosował zręczny manewr podczas XVII Zjazdu partii umożliwiający zostanie przez Xi Jinpinga numerem 6. w Stałym Komitecie Biura Politycznego KPCh. Zob. W. Lam, Changing of the Guard: Beijing Grooms Sixth Generation Cadres for 2020s, The Jamestown Foundation, 09.2010, s. 18. 
Według przewidywań analityków amerykańskich Hu Jintao liczy na wprowadzenie co najmniej trzech swych nowych przedstawicieli do Stałego Komitetu Biura Politycznego:

- dyrektora departamentu organizacyjnego KPCh (kadry) - Li Yuanchao,

- radcę stanu - Liu Yandonga,

- sekretarza partii w Guandong - Wang Yanga.

Wszyscy oni są obecnie zwykłymi członkami Biura Politycznego i ścisłymi protegowanymi Przewodniczącego ChRL. Z kolei wspólne siły „Frakcji szanghajskiej” i „Grupy książąt” pod egidą Jiang Zemina za swój strategiczny cel przyjęły wprowadzenie do Stałego Komitetu Biura Politycznego co najmniej dwóch swych przedstawicieli:

- obecnie pełniącego obowiązki wicepremiera ds. finansów - Wang Qishana,

- członka Biura Politycznego i sekretarza partii w Chongqing - Bo Xilaia lub Han Zhenga, zastępcę sekretarza partii i gubernatora Szanghaju.

W tej konstelacji dwa pozostałe miejsca zostałyby obsadzone przez reprezentantów pozostałych grup politycznego wpływu ${ }^{42}$. Niezależnie od tego, obie frakcje liczą na posiadanie jak najliczniejszych reprezentacji w 25-osobowym Biurze Politycznym.

Eksperci amerykańscy korzystający ze źródeł chińskich szacują również, że ranking prominentów piątej generacji przywódców z ich obecnymi funkcjami będzie wyglądał następująco ${ }^{43}$ :

1) Xi Jinping - wiceprzewodniczący ChRL, „Grupa książąt”,

2) Li Keqiang - wicepremier, „Elita Ligi Młodzieży”,

3) Wang Yang - sekretarz KPCh w Guangdung, „Elita Ligi Młodzieży”,

4) Bo Xilai - sekretarz KPCh w Chongqing, „Grupa książąt” lub Han Zheng, zastępca sekretarza partii i gubernator Szanghaju, „Grupa książąt”4",

5) gen. Liu Yuan - komisarz polityczny w Akademii Nauk Wojskowych, „Grupa książąt",

6) Wang Qishan - wicepremier, „Grupa książąt” i „Technokraci”,

7) Zhang Chunxian - sekretarz partii w Xinjiangu, „Technokraci”,

8) Chen Zhu - minister zdrowia, bez przynależności do frakcji,

9) Wang Gang - minister nauki i technologii, bezpartyjny,

10) Zhang Qingli - sekretarz KPCh w Tybecie, „Elita Ligi Młodzieży”,

42 Ibidem, s. 46

43 Ibidem, s. 47

44 W przypadku usunięcia na stałe z życia publicznego Bo Xilaia w związku ze skandalem politycznym dotyczącym jego, jego małżonki i współpracownika, miejsce po nim w przyszłych władzach zajmie najprawdopodobniej obecnie urzędujący gubernator Szanghaju - Han Zheng, co pozwoli zachować dotychczasowe proporcje udziału w rankingu przywódców obu głównych frakcji w KPCh. 
11) Liu Qibao- sekretarz KPCh w Syczuanie, frakcja „Elity Ligi Młodzieży”;

12) Zhan Xialai - sekretarz generalny KPCh w Anhuai, „Elita Ligi Młodzieży”.

W powyższym zestawieniu widoczna jest równowaga sił pomiędzy poplecznikami Hu Jintao i Jiang Zemina. Biorąc pod uwagę fakt, że współzawodnictwo między frakcjami w promowaniu swych kandydatów do najwyższych centralnych władz i partii nie jest ukierunkowane na podważanie lub negowanie modelu pokoleniowego przekazywania władzy, ranking ten może się w znacznym stopniu sprawdzić. Jednakże do pewnych już tradycji w KPCh i łączących partie różnych w niej koterii i układów personalnych należy prowadzenie przez rządzących swoistych gier personalnych dyskredytujących przeciwników politycznych oraz eliminowania ich $\mathrm{z}$ rywalizacji o pozycję $\mathrm{w}$ rankingu przyszłych prominentów.

Dla przykładu, Jiang Zemin po przejęciu władzy zmusił KC KPCh do odwołania Chen Xitonga, burmistrza Pekinu, oskarżając go o korupcję i czerpanie korzyści finansowych na rzecz swej rodziny. W odwecie Hu Jintao za swej kadencji zdymisjonował i osadził w więzieniu Chen Liangyu, burmistrza Szanghaju za korupcję (25 mld RMB) i zdefraudowanie funduszu emerytalnego ${ }^{45}$. Tak więc o faktycznym kształcie elity piątej generacji przywódców będzie jeszcze decydować czynnik personalnych rozgrywek, który obecni i przyszli rządzący mogą wykorzystywać do walki politycznej w ramach partiii ${ }^{46}$.

W tym kontekście głośnym echem również poza granicami kraju odbiła się sprawa zgłoszenia się 6 lutego 2012 roku do amerykańskiego konsulatu w Chengdu Wang Lijiuna wicegubernatora Chongqing. Jest on protegowanym i bliskim współpracownikiem Bo Xilaia, sekretarza partii w tej prowincji, który aspiruje do numeru 4. we władzach piątej generacji przywódców. Zdarzenie to miało miejsce na dwa dni przed oficjalną wizytą Xi Jinpinga w USA. Według mediów hongkońskich całodniowy pobyt Wang Lijiuna w urzędzie konsularnym USA wykraczał poza wymiar dyplomatyczny, a okoliczności zdarzenia dyskredytują KPCh. Taką opinię ostrożnie podzielają także obserwatorzy pekińscy. Znając realia chińskie, wydaje się, że kariera polityczna Bo Xilaia, który stał się gorącym propagatorem powrotu norm maoistowskich do polityki chińskiej i zakłócenia dotychczasowego kursu ideologicznego Chin,

45 Chen Liangyu został skazany na osiemnaście lat więzienia. Pikanterii temu dodaje fakt, że ze zdefraudowanych funduszy finansowano firmy zatrudnione pod budowę infrastruktury Igrzysk Olimpijskich w Pekinie w 2008 roku oraz EXPO 2010 roku w Szanghaju. Jego aresztowanie było ostatnim aktem Hu Jintao w walce z kliką Jiang Zemina o supremację na najwyższym szczeblu władzy.

$46 \mathrm{~W}$ rozmowie $\mathrm{z}$ autorem artykułu Chińczyk znający realia w strukturach władzy stwierdził w celu egzemplifikacji problemu i skali korupcji w Chinach, że gdyby rozstrzelać losowo wybranych 100 przedstawicieli niższego, średniego, a nawet najwyższego szczebla władz pod zrzutem korupcji, to w $99 \%$ przypadkach kara śmierci byłaby uzasadniona. 
stanęła tym samym pod znakiem zapytania ${ }^{47}$. Następne zdarzenia pokazały bezwzględność konfliktu pomiędzy Bo Xilaiem a premierem Wen Jiabao w międzyfrakcyjnej walce o władzę, za której kulisami sekretarz partii w Chongqing aspirował ze swą charyzmą i postulatami wzmocnienia roli państwa w dalszej modernizacji Chin do przejęcia pełnej kontroli nad KPCh. W marcu 2012 roku został on pozbawiony stanowiska i tymczasowo aresztowany ${ }^{48}$.

\section{Szósta generacja przywódców}

Zgodnie $\mathrm{z}$ charakterem procesu doboru nowych władz obecne kierownictwo KPCh przygotowuje się przed XVIII Zjazdem do wyznaczenia i awansowania na ministerialne stanowiska nowych liderów szóstej generacji przywódców, urodzonych w latach 60., którzy przejęliby rządy podczas XX Zjazdu partii w 2022 roku $^{49}$.

Hu Jintao wzorem Deng Xiaopinga wskaże następców ekipy Xi Jinping i Li Keqiang, a jej liderów awansuje na członków Biura Politycznego. Biorąc pod uwagę preferencje kadrowe obecnego przewodniczącego ChRL, a także jego pragmatyzm w decyzjach personalnych, należy oczekiwać, że kryteria doboru będą pochodną dalekosiężnej percepcji przez obecnych liderów zagrożeń i potrzeb, przed jakimi staną Chiny w okresie najbliższej dekady. Niewątpliwie dla Hu Jintao po starciach z Jiang Zeminem i jego protegowanymi w kwestii struktury personalnej liderów piątej generacji przywódców jest to okazja do przejęcia przez jego frakcję kontroli nad kształtem kolejnej, szóstej generacji przywódców i plasowania w niej własnych kandydatów.

47 Władze w Pekinie wdrożyły śledztwo w tej sprawie. Wang Lijiun przebywał cały dzień na terenie placówki amerykańskiej, po czym sam ją opuścił. Wcześniej placówka została otoczona siłami specjalnymi policji. Wicegubernator został następnie przetransportowany pod eskortą funkcjonariuszy Ministerstwa Bezpieczeństwa Publicznego do Pekinu, gdzie rozpoczęły się przesłuchania. Wang Lijiun wraz $\mathrm{z}$ podległą mu policją $\mathrm{w}$ prowincji pomógł Bo Xilaiowi $\mathrm{w}$ walce $\mathrm{z}$ chińskimi triadami i wszechobecną korupcja, doprowadzajac do ponad 3 tys. aresztowań, dziewięciu $\mathrm{z}$ aresztowanych zostało skazanych na karę śmierci. Zob. U.S. says Bo's ally did go to consulate, „South China Morning Post”, Friday, 10.02.2012, s. 1, A8, a także Speculation rampant on Wang's consulate visit, „South China Morning Post”, Saturday, 11.02.2012, s. A5. Według „The Economist” Wang Lijiun jest podejrzany o korupcję, chińskie władze prowadzą wobec niego śledztwo, a on sam udał się do amerykańskiego konsulatu po azyl. Hidden news, "The Economist" 11.02.2012, s. 53.

48 Bo Xilai został oskarżony o malwersacje finansowe związane $\mathrm{z}$ olbrzymimi przelewami na jego ukryte konta do Hongkongu, w czym miał mu pomagać znaleziony martwy w listopadzie 2011 roku w hotelu w Chongqing brytyjski biznesmen Neil Heywood. W jego śmierć zamieszana ma być żona Bo Xilaia - Gu Kwilai. Brytyjczyk miał sponsorować studia ich syna na Oxfordzie. Bo Xilai został ponadto oskarżony o zastosowanie urządzeń podsłuchowych wobec Hu Jintao.

49 Należy podkreślić, iż zgodnie z założeniami tzw. wielkiej strategii do 2020 roku Chiny mają uzyskać status państwa rozwiniętego. Zob. M. Kostrzewa, op.cit., s. 44-45. 
Wśród 40-50-letnich obecnie członków partii szczególnie wyróżniają się dwie postaci, które są na ścieżce dynamicznego rozwoju kariery mogącej prowadzić do kierowania szóstą generacją przywódców i przewodzenia za dziesięć lat ChRL. Zostali oni wykształceni w szkole partyjnej (pełnili w niej też funkcje sekretarzy) oraz szybko sprawdzeni na centralnych i regionalnych stanowiskach. Dotyczy to $\mathrm{Hu}$ Chunhua $^{50}$, obecnego sekretarza partii w Mongolii Wewnętrznej, oraz Zhou Qianga, sekretarza partii w prowincji Hunan. Mają oni szansę wejścia w 2012 roku w skład Biura Politycznego KPCh. Obu łączy pochodzenie z prowincji Hubei, znanej z tego, iż pochodzą z niej inni liderzy „Elity Ligi Młodzieży”. Do obecnych swych pozycji doszli tradycyjną drogą rozwoju kariery partyjnej, od wyróżniania się w szkole partyjnej, poprzez nominacje gubernatorskie, po objęcie stanowisk sekretarzy KPCh w ważniejszych dla władz centralnych prowincjach.

Doświadczenia Hu Chunhua z wcześniejszych lat pracy w kadrach KPCh w Tybecie, a także w miejscowej gazecie oraz w charakterze menedżera w hotelu w Lahsa na pewno nie pozostają poza polem widzenia Hu Jintao, szczególnie dlatego, że doprowadziły go do awansu w 2005 roku na pierwszego zastępcę sekretarza KPCh w tej prowincji. Otrzymał wtedy z władz centralnych partii zadanie ożywienia gospodarki w Tybecie, ściągnięcia większej liczby Hanów do tej prowincji oraz powstrzymania separatystycznych tendencji wśród Tybetańczyków. Do jego politycznych sukcesów częściowo należy zaliczyć rozpoczęcie 1 lipca 2006 roku funkcjonowania połączenia kolejowego pomiędzy Pekinem a Lahsą. Następnie już jako sekretarz partii wyznaczył sobie za aprobatą władz w Pekinie osobistą odpowiedzialność za utrzymanie stabilizacji społeczno-politycznej w Tybecie ${ }^{51}$. Od 2008 roku jego kariera polityczna i partyjna kontynuowana była w prowincji Hebei, gdzie dość szybko był awansowany od stanowiska wicegubernatora aż do sekretarza partii w 2009 roku. W 2010 roku objął równolegle funkcję przewodniczącego parlamentu i Stałego Komitetu $\mathrm{w}$ tej prowincji ${ }^{52}$.

Zhou Qiang polityczną karierę rozpoczął w 1998 roku, kiedy został mianowany pierwszym sekretarzem w „Komunistycznej Lidze Młodzieży”. W 2006 roku został przeniesiony do prowincji Hunan, gdzie podobnie jak Hu Chunhua był awansowany na coraz wyższe stanowiska po sekretarza KPCh i przewodniczącego parlamentu w 2010 roku. W partii i władzach centralnych zyskał uznanie z powodu zwiększenia

\footnotetext{
${ }^{50} \mathrm{Hu}$ Chunhua nie jest powiązany rodzinnie z Hu Jintao. Przypadkowa jest zbieżność nazwisk pisana w systemie pinyin. Swą karierę zawdzięcza osobistemu wstawiennictwu obecnego przewodniczącego ChRL.

${ }^{51}$ Hu Chunhua: Upholding stability is our priority task, „Legal Daily” 13.04.2010, www. cpc.people. com.cn/GB/64093/64102/11354628.html

52 http://www.chinavitae.com/biography/Hu_Chunhua\%7C3975 (20.02.2012).
} 
w 2009 roku dynamiki rozwoju gospodarczego prowincji do poziomu około $10 \%$ oraz zaangażowania w rozwój ochrony środowiska ${ }^{53}$.

Według Jamestown Foundation ${ }^{54}$ ranking szóstej generacji liderów chińskich władz z obecnymi ich funkcjami może kształtować się następująco, by w 2022 roku znalazł swe on odzwierciedlenie w strukturze personalnej Stałego Komitetu i w całym Biurze Politycznym KPCh:

1) Hu Chunhua - sekretarz KPCh w Mongolii Wewnętrznej, „Elita Ligi Młodzieży,

2) Zhou Qiang - sekretarz KPCh w Hunan, „Elita Ligi Młodzieży”,

3) Sun Zhengcai - sekretarz KPCh w Jilin, ,Technokraci”,

4) Nur Bekri - przewodniczący Autonomicznego Regionu Xinjiang, „Elita Ligi Młodzieży",

5) Lu Hao - pierwszy sekretarz w Lidze Młodzieży Komunistycznej, „Elita Ligi Młodzieży",

6) Zhao Yong - sekretarz KPCh w Tangszan, prowincja Hebei, „Elita Ligi Młodzieży”,

7) Sun Jinlong - sekretarz KPCh w Hewei, stolicy prowincji Anhui, „Elita Ligi Młodzieży",

8) Yang Yue - sekretarz generalny KPCh w Fujian, „Elita Ligi Młodzieży”

9) Zhang Qingwei - przewodniczący Chińskich Komercyjnych Linii Lotniczych, „Technokraci”,

10) Su Shulin - szef SINOPEC, „Technokraci”,

11) Zhu Yanfeng - wicegubernator prowincji Jilin, „Technokraci”,

12) Ling Jihua - dyrektor Biura Generalnego Komitetu Centralnego KPCh, „Elita Ligi Młodzieży",

13) Wang Huning - sekretarz sekretariatu Komitetu Centralnego KPCh, „Frakcja szanghajska",

14) Wang Xiaoochu - Dyrektor Telecom, „Technokraci”,

15) gen. Ma Xiaotian - zastępca szefa Sztabu Generalnego PLA,

16) gen. Zhang Haiyang - Komisarz Polityczny Drugiego Korpusu Artylerii PLA,

17) Li Yuanchao - dyrektor departamentu organizacyjnego KPCh, „Elita Ligi Młodzieży",

18) Lu Zhangong - sekretarz KPCh w Henan, „Technokraci”,

19) Sun Chunlan - sekretarz KPCh w Fujian, „Elita Ligi Młodzieży”,

20) Wang Ming - sekretarz KPCh w Liaoning, ,Technokraci”,

21) Huang Qifan - gubernator w Chongqing, „,Technokraci”.

\footnotetext{
53 http://www.chinavitae.com/biography/Zhou_Qiang\%7C651 (20.02.2012).

${ }^{54}$ Changing of the Guard..., op.cit., s. 48.
} 
W zestawieniu tym uwidacznia się znacząca przewaga absolwentów szkoły partyjnej nad przedstawicielami innych frakcji i grup politycznego wpływu. Eksperci biorą pod uwagę to, że nominowanie nowych członków do Biura Politycznego oraz na najwyższe stanowiska $w$ regionalnych władzach partii jest procesem sterowanym na pewnych zasadach przez odchodzącą elitę przywódców. Na tej podstawie można postawić tezę, że Hu Jintao wykorzystuje swoją obecną pozycję i posiadane wpływy do zapewnienia dominacji frakcji „Elity Ligi Młodzieży” we władzach po 2022 roku i utrzymania przez partię władzy w państwie. Osoba Hu Chunhua daje obecnemu przewodniczącemu ChRL największe ku temu gwarancje. Jego wskazanie na następnego, po przedstawicielu szanghajskiego środowiska partii powiązanego z biznesem, lidera ChRL może ponadto świadczyć o obawach obecnego kierownictwa państwa w kwestii zagrożeń wewnętrznych dla państwa. Na taką percepcję wpływa z pewnością także kontekst międzynarodowy, związany z „arabską wiosną” w Afryce Północnej i na Bliskim Wschodzie. W połowie 2011 roku w Chinach obok wcześniejszych gwałtownych przejawów separatyzmu tybetańskiego i ujgurskiego pojawiły się również protesty mniejszości etnicznej w Mongolii Wewnętrznej, domagającej się polepszenia ich sytuacji życiowej i protestującej przeciwko masowej migracji na ten obszar Hanów, łamiących mongolskie tradycje ${ }^{55}$. Tak więc postawienie przez $\mathrm{Hu}$ Jintao na przewodniczenie ChRL Hu Chunhua, obecnego przedstawiciela partii w Mongolii Wewnętrznej i doświadczonego w pracy partyjnej w Tybecie, na dziesięć lat potwierdzi istnienie w świadomości kierownictwa chińskiego państwa obaw, że separatyzm wewnętrzny o podłożu ekonomicznym i/lub etnicznym stanowi podstawowe zagrożenie dla utrzymania systemu i spójności terytorialnej państwa.

\section{Polityka wewnętrzna i zagraniczna piątej generacji przywódców}

Według RAND Corporation, szczególnie w przypadku znajdujących się w zaawansowanym już procesie „rewitalizacji” Chin, które osiągnęły w nim poziom mocarstwa sektorowego czy też regionalnego, widoczny jest związek pomiędzy sytuacją wewnątrzpolityczną a zachowaniem państwa w stosunkach międzynarodowych. Od 1949 roku polityka chińska jest doktrynalnie określona ramami nadrzędnych wartości dla narodowych interesów chińskich, jakimi są zachowanie suwerenności i integralności terytorialnej, kontynuowanie rozwoju gospodarczego i budowanie

55 Zob. Chiński bunt Mongołów, ,,Rzeczypospolita” 2.06.2011, s. A9. 
międzynarodowego prestiżu oraz mocarstwowej pozycji państwa. Gwarantują one wysoką stabilność celów i strategii prowadzonej polityki zagranicznej ${ }^{56}$. Taką konstrukcję priorytetów dla dotychczasowych czterech ekip rządzących - moim zdaniem - należy uzupełnić jeszcze aksjomatem utrzymania bezpiecznego środowiska w najbliższym otoczeniu Chin. Przy obecnej międzyfrakcyjnej zgodzie w KPCh przed jej XVIII Zjazdem na kontynuację prowadzonych reform pozwala to wraz ze znajomością uwarunkowań wewnętrznych i zewnętrznych na określenie konturów polityki wewnętrznej i zagranicznej, jaką może prowadzić kolejna ekipa przywódców chińskich.

Odchodząca generacja przejęła Chiny w 2002 roku jako szóstą, a przekazuje obecnie swym następcom kraj jako drugą i najszybciej rozwijającą się gospodarkę świata (po USA, a przed RFN, Wielką Brytanią, Japonią, Francją), jako mocarstwo gospodarcze znajdujące się na drodze dynamicznego rozwoju, z największymi rezerwami walutowymi na świecie wynoszącymi 3,2 bln dol. ${ }^{57}$ oraz najmniej wśród największych gospodarek dotknięte światowym kryzysem finansowym ${ }^{58}$. W okresie dotychczasowych blisko 34 lat reform gospodarka chińska rozwijała się ze średnim rocznym przyrostem PKB rzędu 10\%. W 1978 roku Chiny wytwarzały około 1\% światowego PKB, by w 2009 roku osiągnąć w nim 8,5\% własny wkład. W 2009 roku stały się największym światowym eksporterem towarów z udziałem w światowym handlu sięgającym około 9\%. Z imponującymi osiągnięciami gospodarczymi kontrastują dane dotyczące dysproporcji stopy życiowej społeczeństwa chińskiego. 10\% populacji, z której 93\% żyje w miastach, kontroluje około 45\% chińskiego dobrobytu. Według Hurung Reasearch Institute w 2011 roku było w Chinach 270 dolarowych miliarderów ${ }^{59}$. Natomiast około 150 mln Chińczyków żyje na granicy ubóstwa za mniej niż 1,25 dol. dziennie. Około 300 mln mieszkańców nie ma dostępu do czystej wody (czyli około 1/3 osób ludności świata). Około 600 mln mieszkańców nie ma wystarczających warunków sanitarnych.

Chiny w okresie dziesięcioletnich rządów ekipy Hu Jintao-Wen Jiabao stały się aktywnym podmiotem stosunków międzynarodowych i nie potrzebują już pomocy

56 E.S. Medeiros, China's International Behavior. Activism, Opportunism, and Diversification, RAND Corporation, New York 2009, http://www.rand.org/pubs/monographs/MG850.html (27.02.2012).

57 Według danych na grudzień 2011 roku.

58 Udział Chin w światowej gospodarce liczony poprzez uzyskiwany PKB rocznie per capita w 2011 roku plasuje to państwo na 117 miejscu na świecie.

59 Według Ruperta Hoogewerfa, autora rocznego raportu Huron Reasearch Institute, w Chinach żyje większa liczba dolarowych miliarderów, być może nawet około 500. Dane z raportu są szacunkowe, gdyż Chińczycy obawiają się ujawniania informacji dotyczących swojego dobrobytu. Według listy najbogatszych ludzi magazynu „Forbes” w USA żyje 400 dolarowych miliarderów. Zob. Economics focus. How to get a data, „The Economist” 31.12.011, s. 57. 
do umocowania w konstrukcjach politycznych i gospodarczych układu światowego ${ }^{60}$. Przywódcy chińscy nie mają już żadnych kompleksów w kontaktach i utrzymywaniu dialogu na najwyższych szczeblach ze swymi anglosaskimi czy też europejskimi partnerami. W ostatniej dekadzie bardziej dojrzała stała się dyplomacja chińska, zręcznie realizująca swoje zadania polityczne i wspierająca cele gospodarcze i kulturowe również poza azjatyckim kontynentem. Chińska dyplomacja przejawiała zdolność do przyjmowania asertywnych postaw nawet wobec swych najważniejszych partnerów. Sukcesy w przygotowaniu i bezpiecznym zorganizowaniu Igrzysk Olimpijskich 2008 roku w Pekinie, światowego EXPO 2010 w Szanghaju, pomyślna realizacja kolejnych programów badania przestrzeni kosmicznej, a szczególnie osiągnięcie zdolności do zarządzania tego rodzaju programami nie tylko wpływają na kształtowanie się świadomości elit politycznych i społeczeństwa kraju, lecz również znajdują ujście w rosnących ambicjach dalszego umacniania międzynarodowej i globalnej pozycji państwa.

Czwarta generacja przywódców zdołała również osiągnąć w swej polityce jeden ze swych strategicznych celów o prestiżowym znaczeniu, jakim było i jest nadal wzmocnienie relacji z USA oraz ugruntowanie ich partnerskiego, elitarnego i mocarstwowego wymiaru ${ }^{61}$. Wydaje się, że wymierne i niewymierne korzyści z posiadania równorzędnych relacji $\mathrm{z}$ „numerem jeden” na świecie mogły $\mathrm{w}$ hierarchii priorytetów przewyższyć zadanie utrzymania konstruktywnego dialogu i współpracy w UE, którą Chiny traktują po części jako przeciwwagę dla dominacji amerykańskiej na świecie. W polityce wewnętrznej okresu rządów Hu Jintao-Wen Jiabao zaznaczyły się zdecydowanymi reakcjami i brakiem jakiejkolwiek elastyczności w podejściu do ruchów społeczno-politycznych o podłożu separatystycznym, w tym również w protestów w 2008 roku w Tybecie. W kwestii Tajwanu władze w Pekinie stanowczo odpowiedziały na perspektywy wzrostu tendencji separatystycznych wyspy, uchwalając tzw. ustawę antysecesyjną ${ }^{62}$. Odchodzący obecnie przywódcy pozostawiają rów-

60 Jest to odniesienie do zasady „responsible stakeholder”, którą USA wprowadziły do swej polityki w 2005 roku. Zgodnie z nią Chiny przy pomocy USA powinny stać się odpowiedzialnym uczestnikiem społeczności międzynarodowej. Kwestią dyskusyjną jest tutaj problem odpowiedzialności Chin, a jego amerykańska wykładnia nie jest akceptowana po stronie chińskiej, która twierdzi, iż amerykańska teoria o „chińskiej odpowiedzialności” rażąco odbiega od rzeczywistego chińskiego zaangażowania w problemy światowej polityki, gospodarki i bezpieczeństwa. Zob. Ma Zhengang, China's Responsibility and the 'China Responsibility Theory', „China International Studies” Summer 2007, s. 5-12.

${ }^{61} \mathrm{~W}$ ostatniej dekadzie dyplomacja chińska oraz materiały naukowe chińskich autorów obfitowały w określenia o wyjątkowym, konstruktywnym i partnerskim znaczeniu stosunków amerykańskochińskich w każdym ich wymiarze oraz o potrzebie ich dalszego rozwijania. Zob. przykładowo: Yang Jiemian, Push and Pull Factors In China-U.S. Cooperation In the New Era, „China International Studies” 09/10.2010, s. 33-47 oraz Teng Jiangqun, The Third-Party Factors in China-U.S. Relations, „China International Studies" 01/02.2011, s. 62-79.

62 Władze w Pekinie uznały w ustawie, iż mogą użyć środków militarnych i podjąć stosowne kroki w przypadku, gdy całkowicie zostaną wyczerpane inne możliwości powstrzymania tendencji secesjonistycznych na Tajwanie. 
nież wysoko zmodernizowaną w ostatniej dekadzie i dopasowaną do najwyższych standardów militarnych armię chińską.

Jednocześnie Chiny wchodzą w nowy etap rządów jako państwo wielu kontrastów. Nadal nierozwiązane są poważne problemy społeczne, których potencjał partia próbuje umiejętnie kanalizować i wykorzystywać dla uzasadnienia utrzymania przez nią władzy. Mają one odniesienie do sytuacji bytowej znacznej części społeczeństwa. Ponadto wyrazem wzrostu jego świadomości przykładowo w sferze ekologicznej jest fakt, iż od 2000 roku o blisko 30\% zwiększyła się liczba protestów społecznych związanych z zanieczyszczeniem i brakiem ochrony środowiska naturalnego. Odrębnym problemem, z którym przyjdzie się zmierzyć kolejnym generacjom przywódców, będzie kwestia nacjonalizmu, który mimo że w przypadku Chin ma ewidentnie reakcyjny charakter i wydaje się być kontrolowany, a zarazem sterowany przez władze, to jednak wraz z kolejnym etapem rozwoju tego państwa może stać się w większym stopniu kłopotliwym problemem dla władz niż wyłącznie ich politycznym instrumentem.

W ocenie Z. Brzezińskiego jest mniej prawdopodobne, aby niezadowolenie społeczne w Chinach wywoływało oddolne tendencje do demokratyzacji systemu, a bardziej prawdopodobne, że będzie znajdowało ujście przez protesty społeczne lub wzrost nacjonalistycznych postaw. Kolejne ekipy władz są bardziej świadome od swych poprzedników istoty tego zagrożenia i są na nie przygotowane. Paradoksem chińskiej przyszłości jest to, że potencjalna ewolucja systemu i dalsza absorpcja wybranych elementów demokracji zachodnich może mieć miejsce w trakcie silnego, lecz asertywnego kierownictwa państwa, które będzie w stanie ostrożnie sterować oddolną presją społeczną w kierunku większego udziału społeczeństwa w sprawowaniu rządów. Chińscy planiści oficjalnie identyfikują pięć głównych obszarów, które ich zdaniem posiadają potencjał zagrożeń dla stabilności wewnętrznej: dysproporcje społeczne na tle ekonomicznym, protesty miejskie, korupcja, bezrobocie oraz utrata zaufania społecznego ${ }^{63}$.

W dotychczasowej polityce zagranicznej państwa widoczne jest silne skoncentrowanie się na procesach rozwoju gospodarczego. Działania chińskiej dyplomacji ukierunkowane są nadal na strategiczne zapewnienie bezpieczeństwa politycznego, ekonomicznego, energetycznego i militarnego dla utrzymania wysokiej dynamiki gospodarczej i tworzenia ku temu sprzyjających warunków ${ }^{64}$. Chiny przez wiele lat nie próbowały zmieniać układu globalnych zasad, norm i instytucji. Podejmowały raczej wysiłki w celu lepszego ich wykorzystywania dla ochrony własnych interesów.

${ }^{63}$ Z. Brzeziński, Strategic Vision. America and the Crisis of Global Power, Basic Books, New York 2012, s. 170.

${ }^{64}$ Por. M. Kostrzewa, op.cit., s. 44. 
Unikały otwartej konfrontacji z USA, aczkolwiek sukcesywnie rozwijały politykę wypierania amerykańskich wpływów z Azji Wschodniej i Południowej. Według ekspertów amerykańskich jak dotychczas raczej grawitowały wokół określonego problemu w stosunkach z USA, niż wchodziły w konfrontację ze swym głównym partnerem ${ }^{65}$.

Światowy kryzys finansowy 2007 roku i jego konsekwencje, w tym obecny kryzys strefy euro, poprawił globalną pozycję państwa, utwierdził elity chińskie w przekonaniu o rozwijaniu efektywniejszego w porównaniu z zachodnim, własnego modelu gospodarczego. Nastąpiła zmiana w dotychczas zachowawczej dyplomacji chińskiej. Od tego czasu polityka zagraniczna stała się bardziej ofensywna, wychodząca poza obszar Azji i Pacyfiku, otwarcie podważająca światowe zasady handlu, organizacji gospodarczej, międzynarodowych stosunków finansowych i instytucji. Jej celem wydaje się być testowanie możliwości modyfikacji współpracy międzynarodowej, aby stała się ona bardziej korzystna dla ich interesów. Poprzez ten pryzmat należy interpretować wysiłki uczynienia juana walutą międzynarodową, chińskie stanowisko odnośnie do reformy MFW, odrzucenie propozycji USA na rzecz powstania G-2, gotowość do rozwijania współpracy ramach BRIC ${ }^{66}$, a także warunki, jakie postawiła strona chińska w kwestii ewentualnego udzielenia pomocy finansowej UE. W opinii ekspertów brytyjskich Chiny chcą obecnie definiować lub przynajmniej pomagać w określaniu nowych zasad rozwoju świata, a ich liderzy liczą na swą obecność wśród kluczowych architektów instytucji globalnych ${ }^{67}$. Wyraźna tendencja kształtowana aspiracjami liderów chińskich do globalnego traktowania ich państwa oraz uznawania go w praktyce politycznej jako mocarstwa stoją $\mathrm{w}$ dysproporcji $\mathrm{z}$ posiadanymi przezeń atrybutami, wśród których Chiny posiadają tylko ich zasadniczą częśćc ${ }^{6}$.

Pewną odsłoną politycznego stylu i zachowania nowych liderów w aktywności międzynarodowej była oficjalna wizyta Xi Jinpinga jako wiceprzewodniczącego ChRL w USA (13-17 lutego 2012 roku). Podczas wizyty i spotkania z prezydentem Barackiem Obamą pokazał osobowościową stronę nowej ekipy, prezentując jasno interes i stanowisko ChRL wobec omawianych kwestii, unikając konfrontacyjnej postawy. W przypadku poruszanego problemu praw człowieka zmienił dotychczasową taktykę szybkiej „riposty” swych poprzedników wobec amerykańskiej krytyki

65 E.S. Medeiros, op.cit.

66 Zob. szerzej na ten temat: A. Małkiewicz, Oś Brazylia-Rosja-Indie-Chiny?, „Studia Geopolitica”, Rocznik Polskiego Towarzystwa Geopolitycznego, 2010/2011, s. 31-70.

67 Opinia Cheng Li, dyrektora ds. badań w John L. Thornton China Center przy Brookings Institution. Zob. When China Rules The World, „The Economist” 22.03.2010, s. 28.

68 E.S. Medeiros, op.cit. Na temat kryteriów współczesnej mocarstwowości zob. szerzej: S.L. Shirk, op.cit. oraz P. Ostaszewski, Międzynarodowe stosunki polityczne. Zarys wykładów, Książka i Wiedza, Warszawa 2010. 
na bardziej efektywne podejście, akcentując istnienie problemu po obu stronach. Lider piątej generacji polityków chińskich zaprezentował się jako sympatyczny, aczkolwiek pragmatyczny i trudny partner, zainteresowany budowaniem osobistych relacji z prezydentem USA ${ }^{69}$. Taka postawa i zachowanie w kontaktach międzynarodowych Xi Jinpinga kontrastuje z „posągowym” stylem Hu Jintao i może sygnalizować podobną standaryzację zachowań i postaw kolejnej ekipy przywódców w stosunkach międzynarodowych.

Silna tendencja w KPCh do kontynuowania wszechstronnej modernizacji kraju oraz utrzymania wzrostu gospodarczego przy wysokiej stabilności celów chińskiej polityki oraz wyraźnej strategii rozwojowej państwa pozwalają w obliczu sprzyjających okoliczności międzynarodowych dla interesów i prestiżu Chin na przyjęcie założenia, że w polityce piątej generacji przywódców chińskich nie nastąpią zasadnicze zmiany zarówno w jej wymiarze wewnętrznym, jak i zagranicznym. Należy uznać, że dominująca orientacja przyszłościowa chińskiej strategii na osiągnięcie statusu państwa rozwiniętego oraz wizja mocarstwa globalnego nie stwarza pola dla zasadniczej modyfikacji linii dotychczasowej i realizowanych z sukcesem reform. Takim dążeniom i ambicjom sprzyja chińska percepcja stosunków międzynarodowych i zagrożeń bezpieczeństwa ${ }^{70}$. Dla realizacji dotychczasowego tempa i kursu rozwojowego pojawia się natomiast zagrożenie związane z wyraźną tendencją wzmacniania się w KPCh sił konserwatywnych i renesansu skrajnie lewicowych poglądów w sferach społecznych.

W kolejnej dekadzie nowych rządów Chiny najprawdopodobniej dążyć będą do:

- zabezpieczenia stanu swego posiadania przez większą dywersyfikację jego źródeł i instrumentów oraz silniejszego umocowania państwa w stosunkach międzynarodowych;

- kreowania w polityce zagranicznej liberalnego obrazu nowego rządu ChRL na tle bardziej konserwatywnej KPCh;

- zapewnienia swej strategii rozwojowej budowy „socjalizmu z chińską charakterystyką" i utrzymania przez KPCh władzy; obecna pozycja na świecie i sukcesy gospodarcze stają się kreatorem postaw i zachowań przywódców państwa w aktywności zagranicznej;

- utrzymania w polityce zagranicznej dotychczasowych priorytetów przy większej asertywności władz wraz z możliwymi agresywnymi reakcjami wobec problemów

${ }^{69}$ Lianxin Xiang, Firmy grounded, „South China Morning Post”, Thursday, 23.02.2012, s. A15 oraz zob. szerzej dot. programu wizyty: Getting to know you, „South China Morning Post”, Sunday, 12.02.2012, s. 4.

${ }^{70}$ Chińskie władze szacują, że zewnętrzne środowisko bezpieczeństwa jest stabilne na okres kolejnych piętnastu-dwudziestu lat oraz stwarza strategiczne możliwości dla Chin, aby osiągnąć cel „odrodzenia” tego państwa. Zob. E.S. Medeiros, op.cit., summary. 
mających związek z chińskimi interesami politycznymi, gospodarczymi lub bezpieczeństwa, w szczególności w najbliższym otoczeniu;

- ochrony suwerenności i integralności państwa w polityce wewnętrznej;

- utrzymania stabilności wewnętrznej, w tym zdecydowanego neutralizowania ruchów i tendencji separatystycznych;

- utrzymania wysokiego tempa rozwoju gospodarczego i postawienia akcentu w polityce gospodarczej na rozwój konsumpcji wewnętrznej;

- rozszerzania swej ekspansji gospodarczej na świecie wraz z eksportem chińskiej siły roboczej;

- wchodzenia kapitału chińskiego w strategiczne sektory gospodarcze i przemysłowe państw wyżej rozwiniętych, w tym krajów UE;

- kontynuowania procesu wszechstronnej modernizacji armii.

W trakcie rządów piątej generacji przywódców Chiny nie będą raczej dążyć do:

- liberalizacji systemu i demokratyzacji państwa zgodnie z zachodnimi normami;

- rozwijania w polityce zagranicznej czynnika ideologicznego, czy też narzucania alternatywnego modelu strategii rozwoju politycznego i gospodarczego;

- sytuacji konfliktowych z innymi państwami, które mogą wyjść poza kontrolę i zakłócić proces rozwoju gospodarczego państwa;

- militarnej konfrontacji w najbliższym zewnętrznym otoczeniu, z wyjątkiem ewentualności wybuchu konfliktu z USA o Tajwan;

- radykalnych zmian w swym dotychczasowym podejściu do praw człowieka i ich ochrony.

\section{Wnioski}

Przekazywanie władzy przez czwartą generację przywódców zachodzi w warunkach wysokiego stopnia zgodności grup interesów w KPCh odnośnie do generalnej strategii rozwojowej i celów narodowych państwa. Proces ten nie wyjdzie poza partyjny, silnie ugruntowany historycznie, pokoleniowy mechanizm i nie wywoła zagrożeń bezpieczeństwa dla stabilności wewnętrznej Chin.

1. O ile nie wystąpią do 2013 roku nadzwyczajne wydarzenia podważające systemowe i gospodarcze podstawy państwa, istnieje wysokie, graniczące niemal z pewnością prawdopodobieństwo, że transfer władzy do piątej generacji przywódców doprowadzi do nominacji Xi Jinpinga na przewodniczącego oraz Li Keqianga na premiera ChRL. 
2. Korpus piątej i szóstej generacji przywódców kształtowany jest $\mathrm{z}$ dwóch głównych frakcji skupionych wokół Hu Jintao i Jiang Zemina. Pozostałe grupy interesów i politycznego wpływu odgrywają w tych procesach rolę podrzędną. Xi Jinping ma szansę przejąć przywódczą rolę i kontrolę nad skupionymi wokół Jiang Zemina środowiskami biznesowymi.

3. Chiny nie znajdują się w procesie liberalizacji czy też neoliberalizacji systemu. Nie należy oczekiwać dynamicznego wprowadzania reform politycznych. Autorytaryzm w Chinach zostanie utrzymany, a doskonalenie systemu będzie prawdopodobnie bardziej ewoluowało w kierunku zbliżania się do modelu Singapuru niż do rozwiązań demokracji zachodnich.

4. Występujące na szczeblach lokalnych KPCh zjawisko renesansu maoizmu i norm egalitaryzmu napotyka sprzyjające uwarunkowania społeczne. Będzie ono nabierało coraz większego znaczenia $\mathrm{w}$ debatach partyjnych i może obciążać procesy decyzyjne kierownictwa państwa. Tym niemniej w perspektywie następnych dziesięciu lat zagrożenie odwrotu Chin od zasadniczego kursu rozwojowego wydaje się być znikome.

5. Odchodząca ekipa rządowa stara się wykorzystać mechanizm transferu władzy do zapewnienia utrzymania przez KPCh kontroli nad modernizacją państwa i ograniczyć warunki dla ewentualnej liberalizacji systemu. Hu Jintao poprzez ten pryzmat typuje liderów szóstej generacji władz. W obawie przed utratą kursu ideologicznego reform dąży on do pozostawienia po 2022 roku kluczowych decyzji politycznych w gestii KPCh nie w Radzie Państwowej ChRL.

6. Wybór Hu Chunhua i Zhou Qianga na członków Biura Politycznego KPCh potwierdzi projekcję oceny obecnego kierownictwa państwa dotyczącej długofalowych zagrożeń dla interesów Chin, wśród których największe są związane $\mathrm{z}$ obawami przed wzrostem w perspektywie następnych dwadziestu lat separatyzmu wewnętrznego oraz niepokojów społecznych na tle etnicznym lub sytuacji ekonomicznej.

7. Sytuacja międzynarodowa sprzyja zwiększeniu przez Chiny dynamiki swej polityki w zabezpieczaniu kluczowych interesów, większej pewności i otwartości w debatach międzynarodowych różnego szczebla, forsowania własnych interesów w instytucjach międzynarodowych oraz większej asertywności i agresywnych zachowań w polityce energetycznej i bezpieczeństwa. 


\section{Policy of the fifth and sixth generation of Chinese leaders. Continuation or changes of the system?}

The author analyzes the problem with the vision of Chinese domestic and foreign policy after the 2012 power transfer to the fifth generation of its leaders. It also discusses appointing the sixth generation of leaders, who are to take over in 2022. In the conclusions and key findings, the author highlights that, at present, there is no threat for the process of power transfer to come out from under the control of the CPC, and not to complete in accordance with its mechanism. One should not expect, however, the liberalization of politics and the state system in China. Larger confidence, higher assertiveness and the rise of global ambitions, along with readiness for the change of global norms and institutions will characterize the foreign policy of the new Chinese central authorities. The author assesses that some threat to the continuation of the undertaken reforms can constitute the renaissance of Maoism that can now be seen in China, and which is supported by some politicians. However, its potential is not dangerous enough to change the course of the modernization process in China. There exists an overall consensus among the fifth and sixth generation of leaders in relation to the national goals and strategy of China. The designation of someone from Inner Mongolia by $\mathrm{Hu}$ Jintao to become a sixth generation leader will confirm long running concerns of state leadership over domestic separatism, and the threat to the system it brings.

\section{La cinquième génération et la sixième génération de dirigeants chinois. Continuité ou rupture?}

Lauteur analyse le problème de l'avenir de la politique intérieure et étrangère de la Chine après le transfert du pouvoir à la cinquième génération de ses dirigeants en 2012. Il discute également la nomination de la sixième génération de dirigeants, qui devrait prendre le pouvoir en 2022. Dans ses conclusions, l'auteur souligne que, à l'heure actuelle, il n'y a pas de risque que le processus de transfert du pouvoir se trouvera hors du contrôle du Parti communiste chinois et il ne sera pas rempli conformément à son mécanisme. Il ne faut pas s’attendre, cependant, à la libéralisation de la politique et du système étatique en Chine. Une plus grande confiance, une plus grande assurance et une montée des ambitions mondiales, ainsi qu'une préparation pour le changement des normes et des institutions mondiales vont caractériser la politique étrangère des autorités centrales chinoises. Selon l'auteur, 
certaines menaces à la poursuite des réformes entreprises peuvent constituer la renaissance du maoïsme observée en Chine, qui est soutenue par certains politiciens. Cependant, sont potentiel n'est pas suffisamment dangereux pour changer le cours du processus de modernisation en Chine. Il y a un consensus général parmi les leaders de la cinquième et sixième génération concernant les objectifs nationaux et la stratégie de la Chine. La désignation d'une personne de la Région autonome de Mongolie-intérieure par $\mathrm{Hu}$ Jintao à devenir un leader de la sixième génération confirmera les préoccupations des dirigeants de l'État sur le séparatisme national et la menace potentiel pour le système. 